\begin{tabular}{|l|l|}
\hline $\begin{array}{l}\text { 2. To: (Receiving Organization) } \\
\text { Distribution }\end{array}$ & $\begin{array}{l}\text { 3. From: Coriginating Organization) } \\
\text { Process Engineering Analys is }\end{array}$ \\
\hline 5. Proj./Prog./Dept./Div.: & $\begin{array}{l}\text { 6. Design Authority/ Design Agent/cog. } \\
\text { W-030 }\end{array}$ \\
\hline K. Sathyanarayana \\
\hline
\end{tabular}

8. Originator Remarks:

The Cognizant Engineer has initialed to acknowledge the misuse of white-out and validate this form.

11. Receiver Remarks: 11A. Design Baseline Document? [] Yes [X] No W.

\begin{tabular}{|} 
4. Related EOT No.: \\
N/A \\
\hline N. Purchase order No.: \\
N/A
\end{tabular}

9. Equip./Component No.: N/A

10. System/Bldg./Facility: N/A

12. Major Assm. Dwg. No.: $N$. N.A

13. Permit/Permit Application No.: $N / A$

14. Required Résponse Date:

\begin{tabular}{|c|c|c|c|c|c|c|c|c|}
\hline 15. & \multicolumn{4}{|c|}{ DATA TRANSMITTED } & $(F)^{\circ}$ & (G) & (H) & (1) \\
\hline $\begin{array}{l}\text { (A) } \\
\text { Item } \\
\text { No. }\end{array}$ & (B) Document/Drawing No. & $\begin{array}{l}\text { (C) } \\
\text { Sheot } \\
\text { No. }\end{array}$ & $\begin{array}{l}\text { (D) } \\
\text { Rev. } \\
\text { No. }\end{array}$ & $\begin{array}{l}\text { (E) Titlo or Description of Data } \\
\text { Transmitted }\end{array}$ & $\begin{array}{l}\text { Approval } \\
\text { Desig- } \\
\text { nator }\end{array}$ & $\begin{array}{l}\text { Reason } \\
\text { for } \\
\text { Trans- } \\
\text { mitral }\end{array}$ & $\begin{array}{c}\text { Origi- } \\
\text { nator } \\
\text { Dispo- } \\
\text { sition }\end{array}$ & $\begin{array}{l}\text { Roceiv- } \\
\text { er } \\
\text { Oispo- } \\
\text { sition }\end{array}$ \\
\hline 1 & HNF-SD-W030-ER-004 & & 0 & $\begin{array}{l}\text { Evaluation of Waste } \\
\text { Temperatures in AWF } \\
\text { Tanks For Bypass Mode } \\
\text { Operation of the } 702- \\
\text { AZ Ventilation System } \\
\text { (Project W-030). }\end{array}$ & & 1 & 1 & \\
\hline & & & & & & & & \\
\hline
\end{tabular}

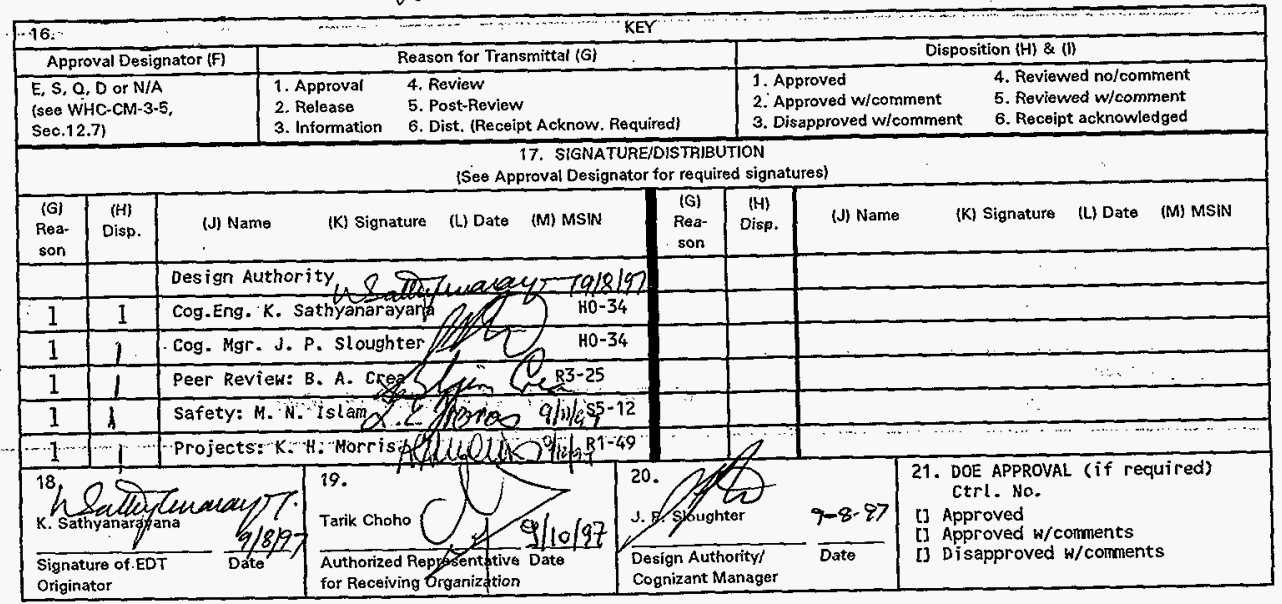

BD-7400-172-2 (05/96) GEF097 


\title{
Evaluation of Waste Temperatures in AWF Tanks For Bypass Mode Operation of the 702-AZ Ventilation System (Project W-030)
}

\author{
K. Sathyanarayana \\ Numatec Hanford Inc., Richland, WA 99352 \\ U.S. Department of Energy Contract DE-AC06-96RL13200
}

$\begin{array}{lll}\text { EDT/ECN: } & 621712 & \text { UC: } 2020 \\ \text { Org Code: } & 8 C 453 & \text { Charge Code: NB604 } \\ \text { B\&R Code: } & \text { EW3135040 } & \text { Total Pages: } 7879\end{array}$

Key Words: Project W-030, Tank 241-AZ-101, Tank 241-AZ-102, Tank 241-AY-101, Tank 241-AY-102 GOTH Computer code.

Abstract: ' This report describes the results of thermal hydraulic analysis performed to provide data in support of Project W-030 to startup new 702-AZ Primary ventilation System. During the startup of $\mathrm{W}-030$ system, the ventilation systen will be operating in bypass mode. In bypass mode of operation, the system is capable of supplying $1000 \mathrm{cfm}$ total flow for all the four AWF doubleshell tanks. The design of $w-030$ system is based on the assumption that both the recirculation loop of the primary ventilation system and the secondary ventilation which provides cooling would be operating. However, during the startup neither of the recirculation system nor the secondary ventilation system wi!l be operating. A minimum $\mathrm{flow}$ of $100 \mathrm{cfm}$ is required to prevent any flammable gas associated risk. The remaining $600 \mathrm{cfm}$ flow can be divided among the four tanks as necessary to keep the peak sludge temperatures below the operating temperature limit. For the purpose of determining the minimum flow required for cooling each tank, the thermal hydraulic analys is is performed to predict the peak sludge temperatures in AY/AZ tanks under different ventilation flows.

The heat load for AZ farm tanks is taken from characterization reports and for the AY farm tanks, the heat load was estimated by thermal analysis using the measured waste temperatures and the waste liquid evaporation rates. The tank 241-AZ-101 and the tank 241-AZ-102 have heat loads of 241,600 and $199,500 \mathrm{Btu} / \mathrm{hr}$ respectively. The tank 241-AY-101 and thank 241-AY-102 have heat loads of 41,000 and $33,000 \mathrm{Btu} / \mathrm{hr}$ respectively. Using the ambient meteorological conditions of temperature and relative humidity for the air and tank dome soil surface and the sludge levels reported in recent document, the peak sludge and supernatant temperatures were predicted for various primary ventilation flows ranging from 100 to $400 \mathrm{cfm}$ for $A Z$ tanks and 100 and $150 \mathrm{cfm}$ for AY tanks. The results of these thermal hydraul ic analyses are presented. Based on the results, it is concluded that $W=030$ operating in bypass mode of operation that the waste peak temperatures can be kept below the operating limit.

TRADEMARK DISCLAIMER. Reference herein to any specific comercial product, process, or service by trade name, trademark, manufacturer, or otherwise, does not necessarily constitute or imply jts endorsement, recommendation, or favoring by the United States Government or any agency thereof or its contractors or subcontractors.

Printed in the United states of America. To obtain copies of this docunent, contact: Document Control Services, P.0. Box 950, Mailstop H6-08, Richland WA 99352, Phone (509) 372-2420; Fax (509) 376-4989.
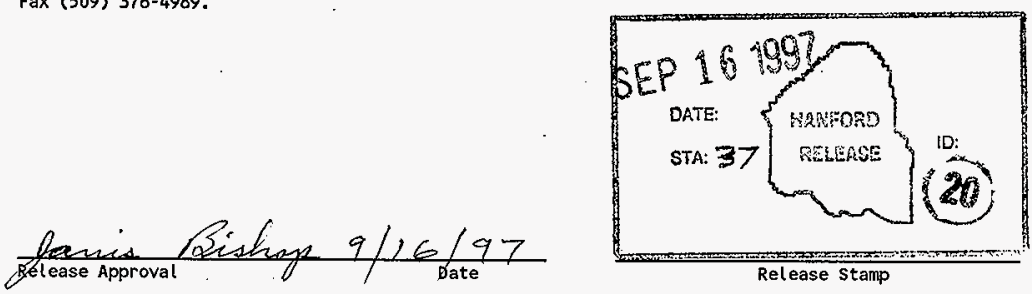

\section{Approved for Public Release}


HNF-SD-W030-ER-004 Rev.0

Evaluation of Waste Temperatures in AWF Tanks

For Bypass Mode Operation of the 702 -AZ Ventilation System (Project W-030)

K. Sathyanarayana

Numatec Hanford Corporation

Richland, Washington

September 10, 1997

Issued by

NUMATEC HANFORD CORPORATION

for the

U.S. DEPARTMENT OF ENERGY

RICHLAND OPERATIONS OFFICE

RICHLAND, WASHINGTON 


\section{SUMMARY}

This thermal hydraulic analysis report describes the current waste temperatures in Aging Waste Facility (AWF) tanks under the operation of 702-A primary ventilation system and summarizes the analyses results for the estimated waste temperatures in all the four doubleshell tanks of AWF under the operation of 702-AZ system (Project W-030) in the bypass mode and assuming that the annulus ventilation is not operating. The bypass mode is one of the normal operation modes for the W-030 system where only the exhaust fan is operated and the fans in the recirculation loops were not operated.

The original design of W-030 system is based on the assumption that both the recirculation loop of the primary ventilation system and the annulus ventilation system which provide cooling for the waste would be operating. However, at startup of W-030 system, the primary ventilation directs dome gases to the common exhaust system bypassing the recirculation ventilation cooling system. Under bypass mode of operation, the system will be able supply a total of $1000 \mathrm{scfm}$ to all four aging waste tanks, namely $241-\mathrm{AZ}-101,241$ AZ-102,241-AY-101 and 241-AY-102. For prevention of flammable gas associated risk, a minimum of $100 \mathrm{scfm}$ flow is required in each tank. The remaining $600 \mathrm{scfm}$ flow can be divided among the four tanks as necessary to keep the peak sludge temperatures below the operating temperature limit. Also the annulus ventilation system, at start-up of W-030, will not be operating.

The heat load data for tanks in AZ farm is assumed as 241,600 Btu/hr for tank AZ-101 and $193,600 \mathrm{Btu} / \mathrm{hr}$ for tank AZ-102 as given in tank waste characterization reports based on radioactive decay estimate. The heat load for tanks in AY farm is assumed as $41,000 \mathrm{Btu} / \mathrm{hr}$ for tank AY-101 and 33,000 Btu/hr for tank AY-102 as determined from thermal analysis. The sludge levels assumed are 35, 95, 94 and $30 \mathrm{Kgal}$ in Tanks AZ-101, AZ-102, AY-101 and AY-102 respectively based on the data. of recent waste tank inventory and status report. The tank dome inlet air was assumed to be at monthly averaged Hanford ambient temperatures and humidity conditions for the year 1995. The tank dome soil surface(ground) temperature was set at these ambient conditions. Using these data and waste parameters, the normal operating peak sludge and supernatant temperatures were estimated for different primary ventilation flows starting from $100 \mathrm{scfm}$ to $550 \mathrm{scfm}$.

Based on the results of these thermal hydraulic analyses, it is concluded that the peak waste temperatures in all of the four tanks can be maintained within the operating limit which is $30^{\circ} \mathrm{F}$ below local boiling temperature. This can be achieved by maintaining $1000 \mathrm{scfm}$ total flow distributed to the two AZ tanks at about $350 \mathrm{scfm}$ for each and to the two AY tanks at about $150 \mathrm{scfm}$ for each. 


\section{CONTENTS}

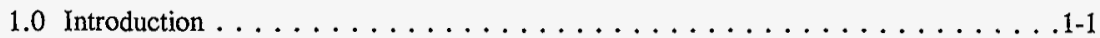

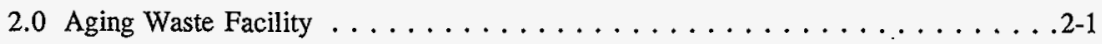

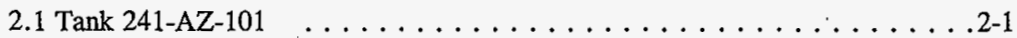

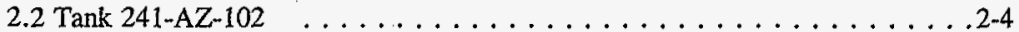

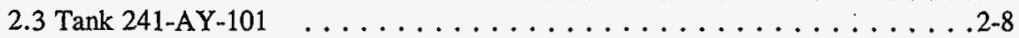

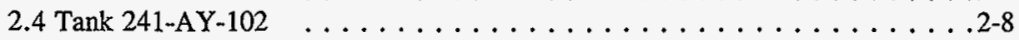

3.0 702-AZ Primary Ventilation System (Project W-030) $\ldots \ldots \ldots \ldots \ldots$. . . . . .

4.0 Methodology and Assumptions $\ldots \ldots \ldots \ldots \ldots \ldots \ldots \ldots$ 4 $\ldots \ldots \ldots$

4.1 GOTH Thermal Hydraulic Model $\ldots \ldots \ldots \ldots \ldots \ldots \ldots \ldots . . \ldots$. . . . . .

4.2 Tank Ventilation Flow Inlet Conditions $\ldots \ldots \ldots \ldots \ldots \ldots \ldots .4 .3$

4.3 Tank Waste Parameters . . . . . . . . . . . . . . 4-3

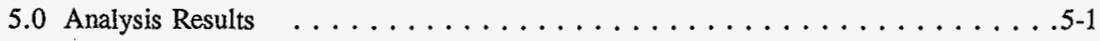

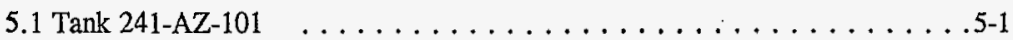

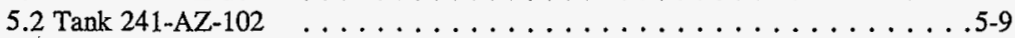

5.3 Tank $241-\mathrm{AY}-101 \quad \ldots \ldots \ldots \ldots \ldots \ldots \ldots \ldots \ldots \ldots \ldots \ldots \ldots \ldots \ldots \ldots .21$

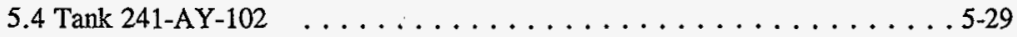

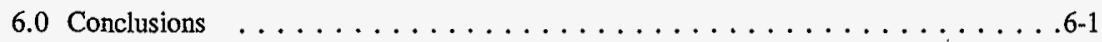

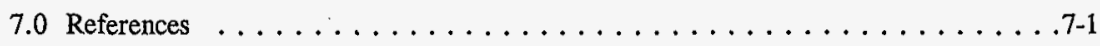


HNF-SD-W030-ER-004 Rev. 0

\section{FIGURES}

2.1 Typical Aging Waste Double-Shell Tank for AZ Tanks . . . . . . . . 2-2

2.2 Measured Waste Temperatures for 241-Tank AZ-101 During August 1996 through

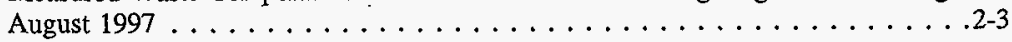

2.3 Typical Aging Waste Tank Cross-Section Showing Radioactive Waste and Coding Air Flow Paths . . . . . . . . . . . . . . . . . . . 2-5

2.4 Measured Waste Temperatures for 241-AZ-102 During August 1996 through August $1997 \ldots$. . . . . . . . . . . . . . . . . . . . . . . . . . . . . 2-6

2.5 Measured Waste Sludge Temperature for 241-AZ-102 During June 1996 through June 1997 Showing Seasonal Variation . . . . . . . . . . . . . . . . . 2-7

2.6 Measured Waste Supernatant Temperature for 241-AY-101 During August 1996

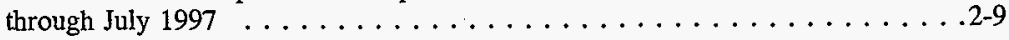

2.7 Measured Waste Sludge Temperatures for 241-AY-101 During May 1996 through

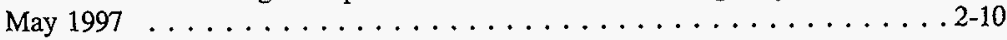

2.8 Measured Waste sludge Temperature at Thermocouple \#143 attached to ALC \#4 for Tank 241-AY-101 During August 1996 through August 1997 . . . . . . . . . . 2-11

2.9 Measured Waste Level for Tank 241-AY-101 During April 1996 through March 1997 . . . . . . . . . . . . . . . . . . . . . . . . . . . . 2-12

2.10 Tank 241-AY-102 Aging Waste Double-Shell Tank Design . . . . . . . . 2-13

2:11 Tank 241-AY-102 Current contents and Primary and Secondary (Annulus and floor) Ventilation . . . . . . . . . . . . . . . . . . 2-14

2.12 Measured Waste Sludge Temperature for Tank 241-AY-102 During August 1996 through August $1997 \ldots \ldots \ldots \ldots \ldots \ldots \ldots \ldots \ldots \ldots$. . . . . . . . . . . . . .

2.13 Measured Waste Supernatant Temperature for Tank 241-AY-102 During August 1996

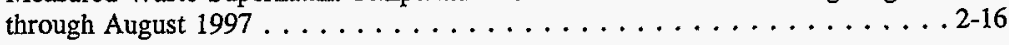

2.14 Measured Waste Level of Tank 241-AY-102 During May 1996 through May 19972-17

3.1 Schematic Diagram of 702-AZ (W-030) Primary Ventilation System . . . . . . . 3-2 
HNF-SD-W030-ER-004 Rev. 0

3.2 Air Flow Path for Recirculation Flow Mode of Operation Ventilation System . . . 3-3

3.3 Air Flow Path for bypass Mode of Operation of 702-AZ (W-030) Primary Ventilation System ......................... . .

3.4 Air Flow Path for High Heat Flow Mode of Operation of 702-AZ (W-030) Primary Ventilation System . . . . . . . . . . . . . . . . 3-5

4.1 GOTH Model for 1-D Heat conduction in Waste and Liquid Waste Evaporation . 4-2

4.2 Monthly Average Ambient Temperature for Five Annual Cycles . . . . . . . 4 4-5

4.3 Monthly Average Ambient Relative Humidity for Five Annual Cycles . . . . . 4-6

4.4 Monthly Average Ambient Saturation Pressure and Steam Partial Pressures . . . 4-7

5.1 : Tank 241-AZ-101 Primary Ventilation Inlet and Outlet Flows For W-030 System Operating in Recirculation Mode $\ldots \ldots \ldots \ldots \ldots \ldots \ldots . \ldots \ldots$. . . . . .

5.2 Tank 241-AZ-101 Waste Sludge and Supernatant Temperatures and Ventilation Flow Inlet and Outlet Temperatures For W-030 System Operating in Recirculation Mode 5-3

5.3 Tank 241-AZ-101 Waste Liquid Evaporation Rate For W-030 System Operating in Recirculation Mode . . . . . . . . . . . . . 5-4

5.4 Tank 241-AZ-101 Waste Sludge and Supernatant Temperatures and Ventilation Flow Inlet and Outlet Temperatures For W-030 System Operating in Bypass Mode With $100 \mathrm{scfm}$ Ambient Inleakage Flow . . . . . . . . . . . . . 5-5

5.5 Tank 241-AZ-101 Waste Sludge and Supernatant Temperatures and Ventilation Flow Inlet and Outlet Temperatures For W-030 System Operating in Bypass Mode With $200 \mathrm{scfm}$ Ambient Inleakage Flow $\ldots \ldots \ldots \ldots \ldots \ldots . \ldots \ldots$

5.6 Tank 241-AZ-101 Waste Sludge and Supernatant Temperatures and Ventilation Flow Inlet and Outlet Temperatures For W-030 System Operating in Bypass Mode With $350 \mathrm{scfm}$ Ambient Inleakage Flow $\ldots \ldots \ldots \ldots \ldots \ldots \ldots \ldots . \ldots \ldots$

5.7 Tank 241-AZ-101 Waste Sludge and Supernatant Temperatures and Ventilation Flow Inlet and Outlet Temperatures For W-030 System Operating in Bypass Mode With $400 \mathrm{scfm}$ Ambient Inleakage Flow $\ldots \ldots \ldots \ldots \ldots \ldots \ldots . . \ldots \ldots$

5.8 Tank 241-AZ-102 Primary Ventilation Inlet and Outlet Flows For W-030 System Operating in Recirculation Mode . . . . . . . . . . . . . . 5-10 


\section{HNF-SD-W030-ER-004 Rev. 0}

5.9 Tank 241-AZ-102 Waste Sludge and Supernatant Temperatures and Ventilation Flow Inlet and Outlet Temperatures For W-030 System Operating in Recirculation Mode-11

5.10 Tank 241-AZ-102 Waste Liquid Evaporation Rate For W-030 System Operating in Recirculation Mode $\ldots \ldots \ldots \ldots \ldots \ldots \ldots \ldots \ldots \ldots \ldots \ldots$ 5-13

5.11 Tank 241-AZ-102 Waste Sludge and Supernatant Temperatures and Ventilation Flow Inlet and Outlet Temperatures For W-030 System Operating in Bypass Mode With $100 \mathrm{scfm}$ Ambient Inleakage Flow . . . . . . . . . . . . . . 5-14

5.12 Tank 241-AZ-102 Waste Sludge and Supernatant Temperatures and Ventilation Flow Inlet and Outlet Temperatures For W-030 System Operating in Bypass Mode With $200 \mathrm{scfm}$ Ambient Inleakage Flow $\ldots \ldots \ldots \ldots \ldots \ldots \ldots \ldots . \ldots \ldots$

5.13 Tank 241-AZ-102 Waste Sludge and Supernatant Temperatures and Ventilation Flow Inlet and Outlet Temperatures For W-030 System Operating in Bypass Mode With $350 \mathrm{scfm}$ Ambient Inleakage Flow $\ldots \ldots \ldots \ldots \ldots \ldots \ldots \ldots$

5.14 Tank 241-AZ-102 Waste Sludge and Supernatant Temperatures and Ventilation Flow Inlet and Outlet Temperatures For W-030 System Operating in Bypass Mode With $400 \mathrm{scfm}$ Ambient Inleakage Flow $\ldots \ldots \ldots \ldots \ldots \ldots \ldots . . \ldots \ldots$

5.15 Tank 241-AZ-102 Waste Sludge and Supernatant Temperatures and Ventilation Flow Inlet and Outlet Temperatures For W-030 System Operating in Bypass Mode With $350 \mathrm{scfm}$ Ambient Inleakage Flow and Heat Load of 199,500 Btu/hr . . . . 5 5-18

5.16 Tank 241-AZ-102 Waste Sludge and Supernatant Temperatures and Ventilation Flow Inlet and Outlet Temperatures For W-030 System Operating in Bypass Mode With $350 \mathrm{scfm}$ Ambient Inleakage Flow and Heat Load of 209,000 Btu/hr . . . . . 5-19

5.17 Tank 241-AZ-102 Waste Sludge and Supernatant Temperatures and Ventilation Flow Inlet and Outlet Temperatures For 702-A Current Operating System With $550 \mathrm{scfm}$ Ambient Inleakage Flow and Heat Load of 209,000 Btu/hr . . . . . 5-20

5.18 Tank 241-AY-101 Waste Sludge and Supernatant Temperatures and Ventilation Flow Inlet and Outlet Temperatures For 702-A Current Operating System With $550 \mathrm{scfm}$ Ambient Inleakage Flow and Heat Load of $41,000 \mathrm{Btu} / \mathrm{hr} \ldots \ldots .55-22$

5.19 Tank 241-AY-101 Waste Liquid Evaporation For 702-A Current Operating System With $550 \mathrm{scfm}$ Ambient In leakage Flow and Heat Load of 41,000 Btu/hr . . . 5-23

5.20 Tank 241-AY-101 Evaporation and Sensible Heat Loss With 702-A Current Operating System With $550 \mathrm{scfm}$ Ambient Inleakage Flow and Heat Load of 41,000 Btu/hr . . . . . . . . . . . . . . . . . . . . . . . . . 5-24 
5.21 Tank 241-AY-101 Waste Sludge and Supernatant Temperatures and Ventilation Flow Inlet and Outlet Temperatures For W-030 System Operating in Recirculation Mode With Heat Load of $38,000 \mathrm{Btu} / \mathrm{hr} \ldots \ldots \ldots \ldots \ldots \ldots \ldots$. . . . . . . . .

5.22 Tank 241-AY-101 Waste Sludge and Supernatant Temperatures and Ventilation Flow Inlet and Outlet Temperatures For W-030 System Operating in Bypass Mode With $100 \mathrm{scfm}$ Ambient Inleakage Flow and Heat Load of 41,000 Btu/hr . . . 5-27

5.23 Tank 241-AY-101 Waste Sludge and Supernatant Temperatures and Ventilation Flow Inlet and Outlet Temperatures For W-030 System Operating in Bypass Mode With $150 \mathrm{scfm}$ Ambient Inleakage Flow and Heat Load of 41,000 Btu/hr $\ldots$ 5-28

5.24 Tank 241-AY-102 Waste Sludge and Supernatant Temperatures and Ventilation Flow Inlet and Outlet Temperatures For 702-A Current Operating System With 500 scfm Ambient Inleakage Flow and Heat Load of 33,000 Btu/hr . . . . . . . 5 5-30

5.25 Tank 241-AY-102 Waste Liquid Evaporation For 702-A Current Operating System With $550 \mathrm{scfm}$ Ambient Inleakage Flow and Heat Load of 33,000 Btu/hr . . . 5-31

5.26 Tank 241-AY-102 Evaporation and Sensible Heat Loss With 702-A Current Operating System With $550 \mathrm{scfm}$ Ambient Inleakage Flow and Heat Load of 33,000 Btu/hr . . . . . . . . . . . . . . . . . . . . . . 5-32

5.27 Tank 241-AY-102 Waste Sludge and Supernatant Temperatures and Ventilation Flow Inlet and Outlet Temperatures For W-030 System Operating in Recirculation Mode With Heat Load of $33,000 \mathrm{Btu} / \mathrm{hr} \ldots \ldots \ldots \ldots \ldots . . . \ldots 53$

5.28 Tank 241-AY-102 Waste Sludge and Supernatant Temperatures and Ventilation Flow Inlet and Outlet Temperatures For W-030 System Operating in Bypass Mode With $100 \mathrm{scfm}$ Ambient Inleakage Flow and Heat Load of 33,000 Btu/hr . . 5 5-34

5.29 Tank 241-AY-102 Waste Sludge and Supernatant Temperatures and Ventilation Flow Inlet and Outlet Temperatures For W-030 System Operating in Bypass Mode With $150 \mathrm{scfm}$ Ambient Inleakage Flow and Heat Load of 33,000 Btu/hr . . 5 5-35 
HNF-SD-W030-ER-004 Rev. 0

\section{TABLES}

4.1 AY/AZ Tank Farm Aging Waste Parameters $\ldots \ldots \ldots \ldots \ldots \ldots$ 4-4

5.1 Tank 241-AZ-101 Waste Temperatures For Different Primary Ventilation Flows . . 5-9

5.2 Tank 241-AZ-102 Waste Temperatures For Different Primary Ventilation Flows . 5-21

5.3 Tank 241-AY-101 Waste Temperatures For Different Primary Ventilation Flows . 5-25

5.4 Tank 241-AY-102 Waste Temperatures For Different Primary Ventilation Flows . 5-29

6.1 Summary of Recommended Ventilation Flow Rates and Predicted Corresponding Waste Temperatures $\ldots \ldots \ldots \ldots \ldots \ldots \ldots$ 6-1 


\subsection{Introduction}

The project W-030 provides an upgraded primary ventilation system for AWF tanks. The ventilation system has been designed to accommodate the thermal input of two mixer pumps with a power of $1.375 \mathrm{E}+06 \mathrm{Btu} / \mathrm{hr}$ in the tank 241-AZ-101 in addition to its waste heat load of $291,000 \mathrm{Btu} / \mathrm{hr}$ and $900,000 \mathrm{Btu} / \mathrm{hr}$ heat load from each of the other three AWF tanks. The design of the system is based on the assumption that both the recirculation loop in the primary ventilation system and the secondary ventilation system which provides some cooling to annulus and tank bottom floor will be operating. However, for the planned start-up of W030 system, neither the secondary ventilation systems for all the four tanks nor the recirculation loops of the primary ventilation system will be available. For a period of time, therefore, only the main exhaust system will be operating with a total ventilation flow rate of $1000 \mathrm{scfm}$.

The current radioactive heat load in the aging waste facility tanks is, however, less than the amount of heat load that was used as the design basis for W- 030 ventilation systems. At start-up of W-030 system, the pumps in tank 241-AZ-101 will not be operating. Also at start-up this system will supply a total of $1000 \mathrm{scfm}$ in once through ventilation mode for cooling and head. space dilution to all four tanks in AY/AZ tank farms. For flammable gas risk prevention, a minimum of $100 \mathrm{scfm}$ is required for each tank. The remaining $600 \mathrm{scfm}$ flow can be shared as necessary among the four tanks. The thermal hydraulic analysis is performed to determine the minimum flow rate required for each of these four tanks so that the waste temperatures will remain within the operating limits. The operating limits for normal operation of waste tanks in regard to temperature are based on the requirement that the waste temperature should remain $30^{\circ} \mathrm{F}$ below the local saturation temperature. This 30 ${ }^{\circ} \mathrm{F}$ sub-cooling provides a safety margin for the potential to cause a steam bump event.

This report describes AY/AZ tank farm and current operating waste temperatures in all the four tanks. The results of thermal hydraulic analysis performed to determine the required minimum primary ventilation flow rates for each tank are presented with the waste temperatures for each ventilation flow rate considered for all four tank. Based on the results of these analysis, it was concluded that it is possible with the proper distribution of the available $1000 \mathrm{scfm}$ flow to ensure that the cooling will be adequate to keep the waste temperatures in all the four tanks below the operating limit. 
A brief description of the aging waste facility tanks in AY/AZ tanks farms is given in Section 2.0 and that of the new ventilation system (W-030) is provided in Section 3.0. The methodology and the assumptions used in the thermal hydraulic analysis are described in Section 4.0. The analysis results are presented in Section 5.0 and the conclusions are provided in Section 6.0. 


\subsection{Aging Waste Facility}

The Aging Waste Facility comprises $A Z$ and AY tank farms. The AZ tank farm contains two one-million gallon and $75 \mathrm{ft}$ diameter double-shell tanks 241-AZ-101 and 241-AZ-102. The AY tanks farm also contains two double-shell tanks of the same capacity. These tanks were designed to hold boiling liquid waste from PUREX and B Plant. Aging waste tanks differ from other double shell tanks such as AP, AW and AN tanks by the addition of two major support systems. These additional systems allow the tanks to receive and store high heat generating wastes with a minimum probability of loss of integrity. These systems include a tank preheating system comprised of a steam coil, steam piping, steam condensate piping, valves, and instrumentation necessary to control the rate of tank preheating and a fluid mixing system comprising 22 airlift circulators and associated instrumentation to control the amount of air flow into the tank. The primary ventilation system is shared between the AZ and AY Tank Farms. These tanks are located in the 200-East area. A typical aging waste double-shell tank configuration for $A Z$ tanks is shown in Figure 2-1.

\subsection{Tank 241-AZ-101}

Tank 241-AZ-101 is one of the two underground double-shell tanks comprising the AZ Tank Farm and is currently categorized as a structurally sound, non-watch list tank with no associated unreviewed safety questions. The tank contains aging waste or neutralized current acid waste (NCAW), which is high-level, first cycle solvent extraction waste from Plutonium and Uranium Extraction (PUREX) plant. The estimated total waste volume is $887 \mathrm{kgal}$ of which $852 \mathrm{kgal}$ is drainable liquid and $35 \mathrm{kgal}$ is sludge (Hanlon 1997).

The heat generation rate (Hodgson 1995) in the waste has been estimated from waste characterization effort. The heat is generated primarily from radioactive decay. The primary contributors for tank $241-\mathrm{AZ}-101$ are $241 \mathrm{Am}, 144 \mathrm{Ce}, 137 \mathrm{Cs}, 106 \mathrm{Ru}$, and $90 \mathrm{Sr}$.The estimated heat generation rate from isotopes in the sludge is $152,000 \mathrm{Btu} / \mathrm{hr}(44.5 \mathrm{KW})$ and the heat generated from the $137 \mathrm{Cs}$ in the supernate is $89,600 \mathrm{Btu} / \mathrm{hr}(26.2 \mathrm{KW})$. The total waste heat load for tank 241-AZ-101 is therefore 241,600 Btu/hr. During 1996-97, the maximum temperature of the waste ranged from $150^{\circ} \mathrm{F}$ to $189^{\circ} \mathrm{F}$. The SACS database (WHC-1996) for Tank 241-AZ-101 has been used to plot typical temperature data that represents the supernatant and sludge.

Figure 2.2 shows the temperature variation during August 1996 to August 1997 at the thermocouple \#65 which is located at 140 in. from tank bottom and so should represent the supernatant temperature. Also shown in this figure is the temperature data for the thermocouple \#10 located at a $21 \mathrm{ft}$ radius in the Southeast quadrant and therefore, should represent the peak sludge temperature. However, the thermocouple \#46 attached to the 
Figure 2.1 Typical Aging Waste Double-Shell Tank in AZ Farm.

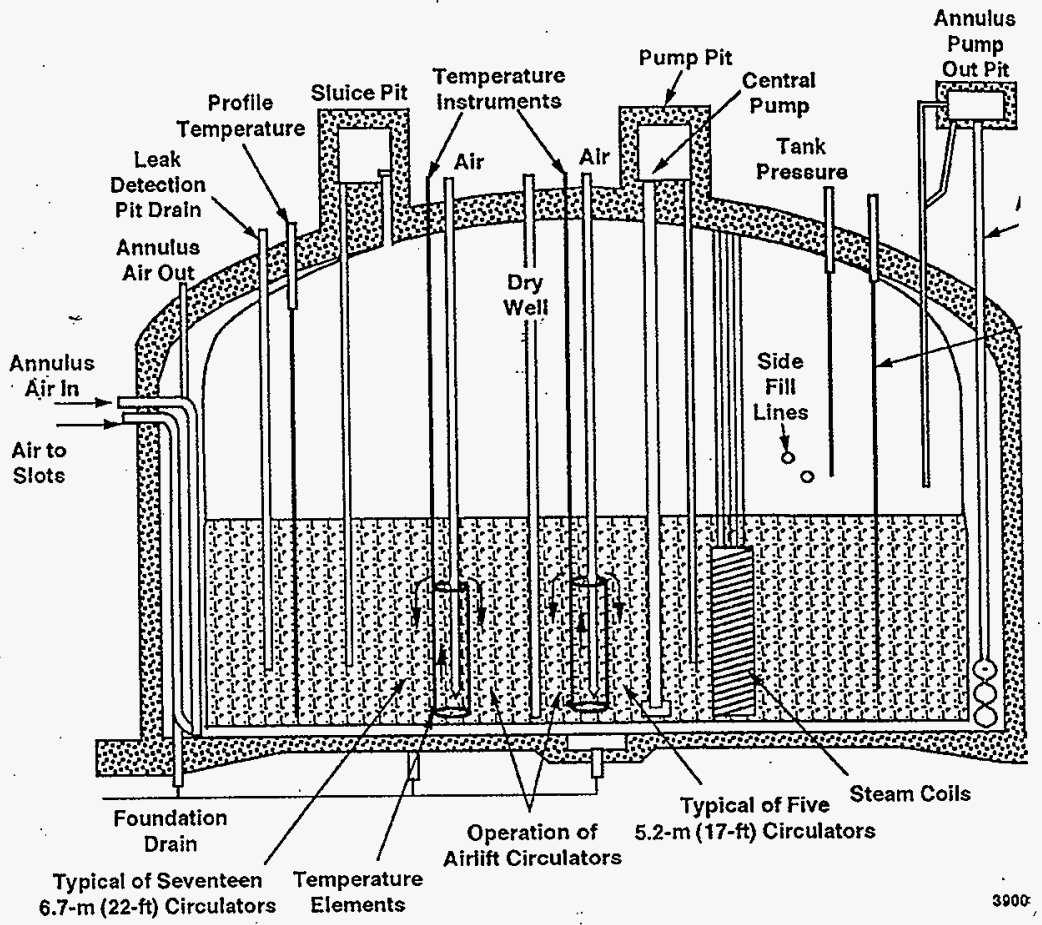


HNF-SD-W030-ER-004 Rev. 0

Figure 2.2 Measured Waste Temperatures for 241-AZ-101 During August 1996 Through August 1997.

Tank 241-AZ-101 Waste Temperatures

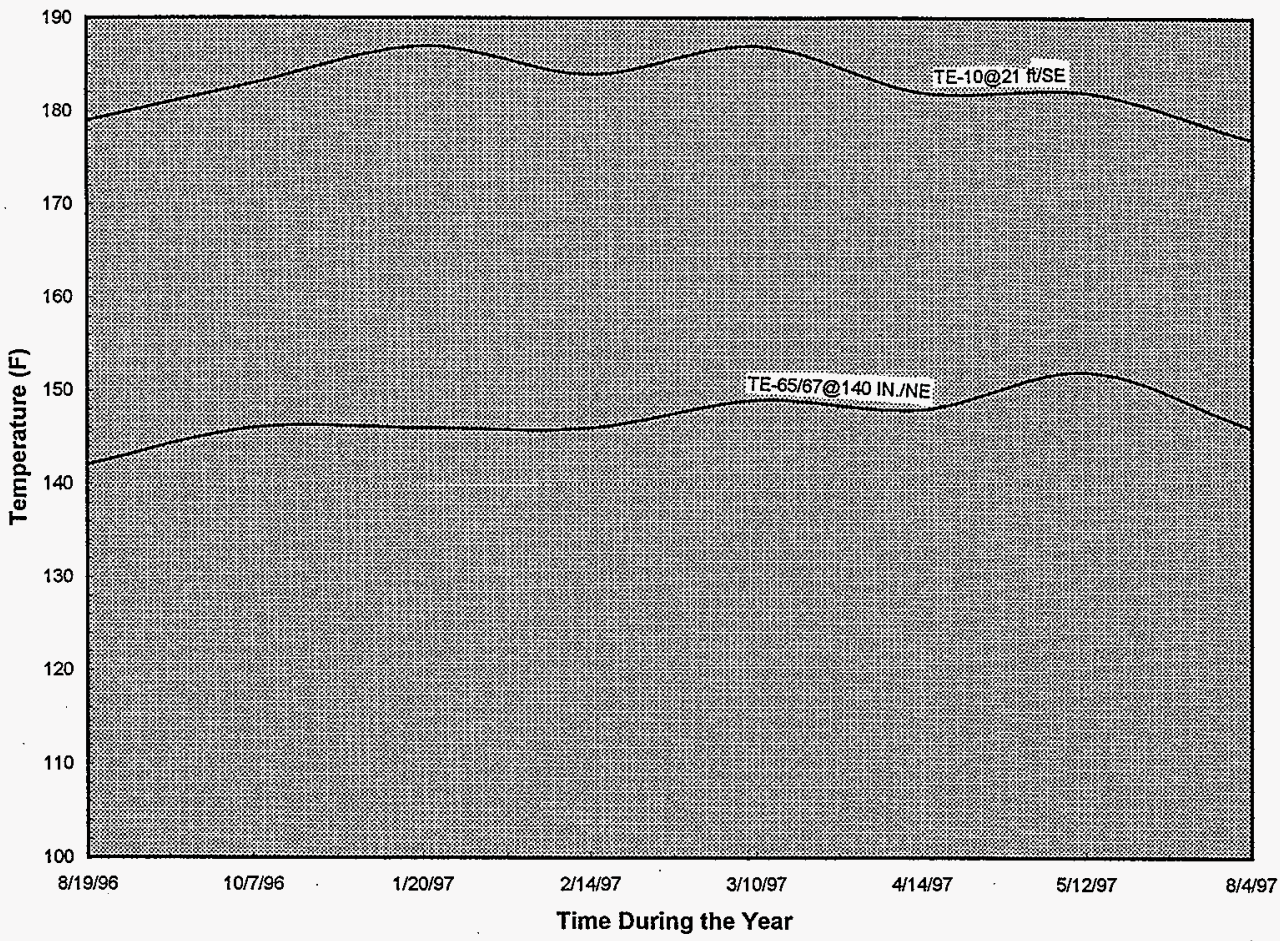


air-lift circulator \#10 and four in. above the tank bottom has indicated a temperature of 197 ${ }^{\circ} \mathrm{F}$ and the thermocouple \#69 located $14 \mathrm{in}$. above the tank bottom has indicated a temperature of $153^{\circ} \mathrm{F}$ during early part of October, 1996. Assuming $15 \%$ vapor pressure suppression, the local saturation temperatures at the waste bottom and surface level will be about 256 and $218^{\circ} \mathrm{F}$ respectively.

\subsection{Tank 241-AZ-102}

Tank 241-AZ-102 is located in the AZ Tank Farm and is designed to store high-level aging waste generated at PUREX Plant and high strontium waste from B Plant. It is very similar to $241-A Z$ Z-101 and has an operating capacity of $980 \mathrm{kgal}$ with a diameter of $75 \mathrm{ft}$ and a usable depth of about $29 \mathrm{ft}$. Tank 241-AZ-102 also has special support systems to allow the tank to store high-heat generating wastes with minimum probability of loss of integrity. These systems include a tank preheating system comprised of a steam coil, a waste mixing system comprised of 22 airlift circulators, and an exhaust condenser system to control condensate in the exhaust stream. The maximum design temperatures for this tank are 355 ${ }^{\circ} \mathrm{F}$ for the sludge, $260^{\circ} \mathrm{F}$ for the supernatant, and $220^{\circ} \mathrm{F}$ for vapor (WHC 1994), currently contains $910 \mathrm{kgal}$ of total waste of which $819 \mathrm{kgal}$ is drainable liquid and $95 \mathrm{kgal}$ is sludge (Hanlon 1997). Figure 2.3 shows schematically sludge and supernatant waste levels, potential waste temperature distribution, the local saturation temperature variation from tank bottom to top waste level due to hydrostatic head and also potential inleakage and exhaust paths of the primary ventilation flow as well as annulus ventilation flow paths. When the sludge temperature reaches local saturation temperature, then the potential for initiation of steam formation, accumulation and eventually a steam bump to occur exist. For safe operation of the tank facilities it is considered necessary to keep the waste temperatures below the saturation values.

The heat generation rate (Schreiber 1995) in the waste has been estimated from waste characterization analysis of heat generating radioactive components. The heat is generated primarily from radioactive decay. The primary contributors for tank 241-AZ-102 are $241 \mathrm{Am}, 144 \mathrm{Ce}, 137 \mathrm{Cs}, 106 \mathrm{Ru}$, and $90 \mathrm{Sr}$.The estimated heat generation rate (MacLean 1995) from isotopes in the sludge is $129,000 \mathrm{Btu} / \mathrm{hr}(37.8 \mathrm{KW})$ and the heat generated from the $137 \mathrm{Cs}$ in the supernate is $64,600 \mathrm{Btu} / \mathrm{hr}(18.9 \mathrm{KW})$. The total waste heat load for tank 241 AZ-102 is therefore $193,600 \mathrm{Btu} / \mathrm{hr}$. During 1996-97, the maximum temperature of the waste ranged from $134^{\circ} \mathrm{F}$ to $187^{\circ} \mathrm{F}$ as shown in Figure 2.4. Figure 2.4 shows the temperature variation for the year August 1996 to August 1997 indicated by thermocouple \#s72 located four in: above tank bottom in southwest quadrant and 60 located 158 in. above tank floor in south east quadrant. Also Figure 2.5 shows the temperature indicated by thermocouple \#72 to a larger scale showing the seasonal variation and the peak occurring October-November time of the year. Assuming $15 \%$ vapor pressure suppression, the local saturation temperatures at the waste bottom and surface level will be about 254 and $215^{\circ} \mathrm{F}$ respectively. 
Figure 2.3 Typical Aging Waste Tank Showing Waste Contents and Temperature . and Cooling Air Flow Paths.

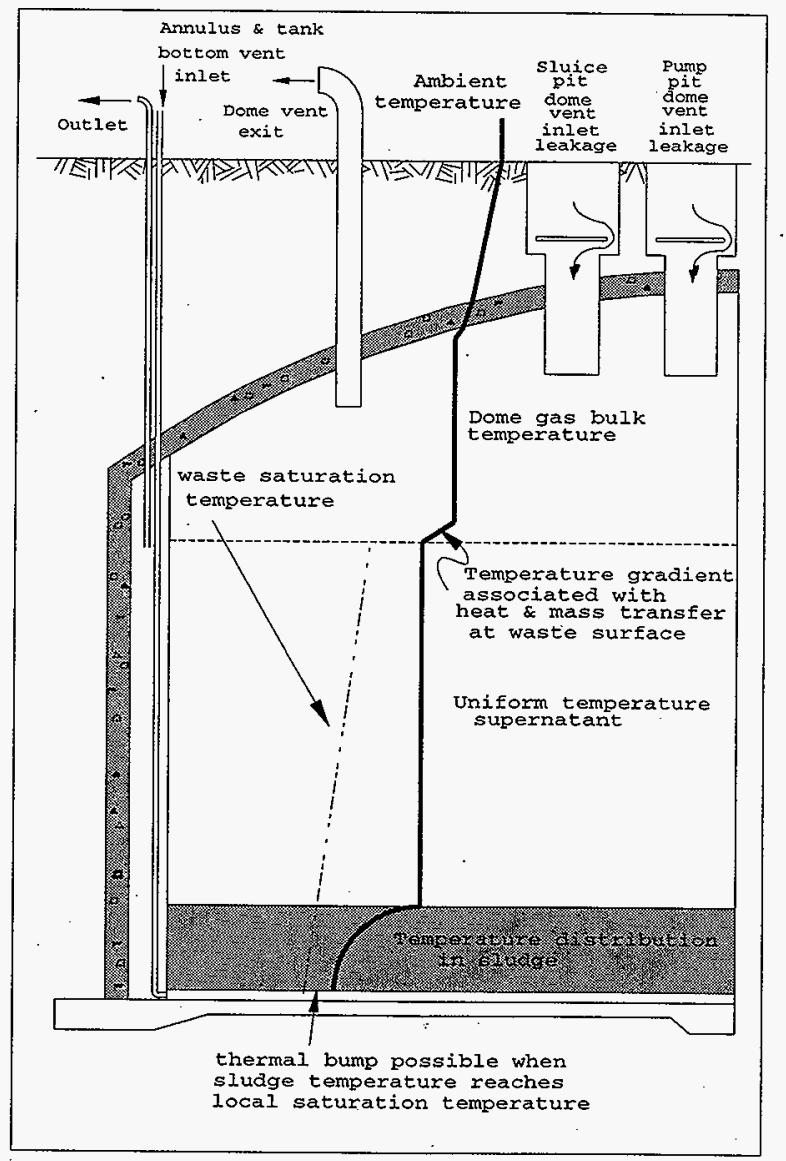


HNF-SD-W030-ER-004 Rev. 0

Figure 2.4 Measured Waste Temperatures For Tank 241-AZ-102 During August 1996 Through August 1997.

Tank 241-AZ-102 Waste Temperatures

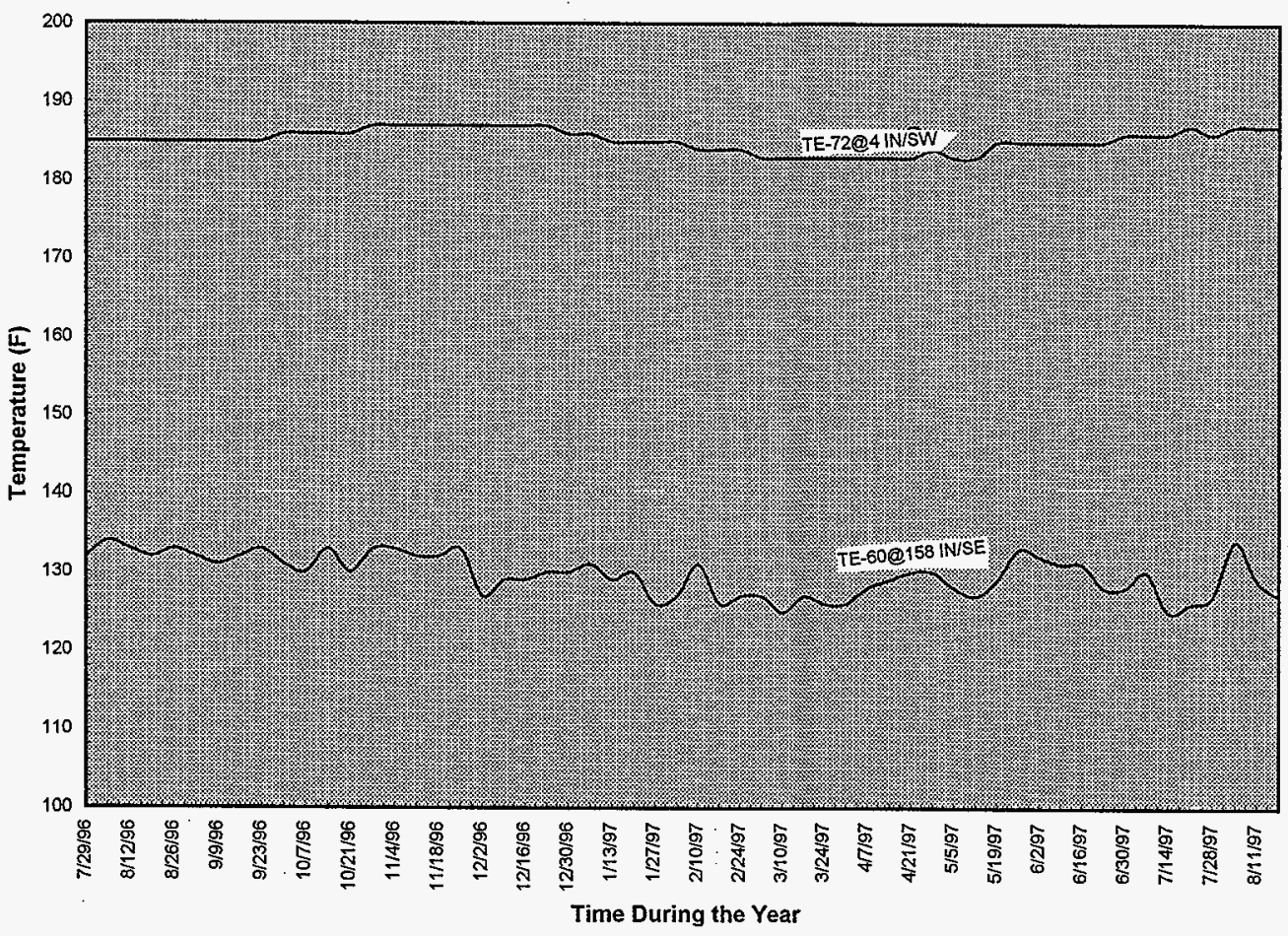


HNF-SD-W030-ER-004 Rev. 0

Figure 2.5 Measured Waste Peak Temperature For Tank 241-AZ-102 During June 1996 Through June 1997 Showing Seasonal Variation.

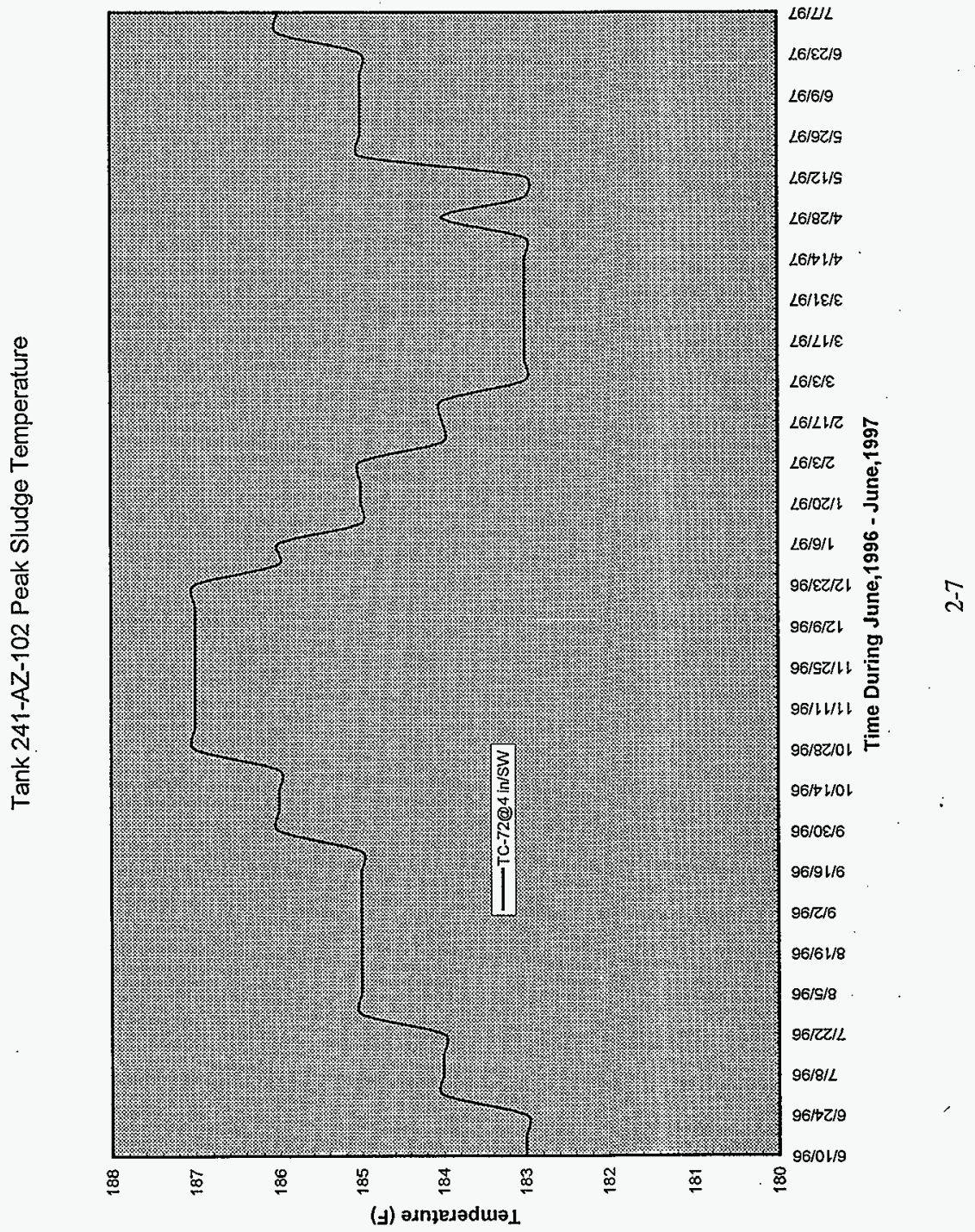




\subsection{Tank 241-AY-101}

Tank 241-AY-101 is one of two double-shell tanks located in the Hanford 200 East Area 241-AY Tank Farm. AY Tank farm is part of the Aging Waste Facility. These tanks are designed to hold boiling waste liquid. The tank AY-101 has a designed capacity of 1000 $\mathrm{kgal}$ with an internal diameter of $75 \mathrm{ft}$ and an operating depth of $30.33 \mathrm{ft}$. Currently the tank contains $906 \mathrm{kgal}$ of waste (Hanlon, 1997). The insoluble solids have settled to form sludge and the sludge has a volume of $94 \mathrm{kgal}(-3 \mathrm{ft})$ with a heat generation rate of about $41,000 \mathrm{Btu} / \mathrm{hr}$ (Sathyanarayana, 1997). The supernatant which has very small or even zero fraction of insoluble solids has a volume of $812 \mathrm{kgal}(\sim 25 \mathrm{ft})$ with no heat generation. All four tanks of the AY/AZ tank farm are served by a single primary ventilation system. The primary ventilation flow rate range from $550 \mathrm{scfm}$ to $580 \mathrm{scfm}$ (Sathyanarayana, 1994) with higher flow rates being driven to higher heat load tanks. For Tank 241-AY-101, it is assumed that a minimum flow rate of $550 \mathrm{scfm}$ is maintained.

Based on SACS database for Tank 241-AY-101, the supernatant temperature at thermocouple 69 is shown in Figure 2-6. The maximum temperature of $76^{\circ} \mathrm{F}$ was recorded during early October 1996. Figures 2-7 and 2.8 shows the sludge temperatures at four thermocouple. The peak temperature was recorded by thermocouple 43 attached to the air-lift circulator \# four and the peak temperature was $116^{\circ} \mathrm{F}$ which occurred during the first week of October 1996. The sludge temperatures range from 85 to $116^{\circ} \mathrm{F}$ during the year at different locations. Assuming $15 \%$ vapor pressure suppression, the local saturation temperatures at the waste bottom and surface level will be about 250 and $219^{\circ} \mathrm{F}$ respectively. Figure 2.9 shows the waste level data for tank 241-AY-101 during the year 1996-97. Based on the waste level data, the liquid evaporation rate was 0.02 in/day during May, 96 to September, 96 and during October, 96 to April, 97 it was 0.0316 in/day. Primary ventilation flow was assumed to $550 \mathrm{scfm}$ and the annulus ventilation system was not operating during this period. However, the annulus ventilation system was restarted on May 29, 1997.

\subsection{Tank 241-AY-102}

Tank 241-AY-102, as illustrated in Figure 2.10, is a double-shell tank and has a design capacity of one million gallons. Currently the tank contains 833,000 gallons of waste (Hanlon, 1997) in the form of supernatant and sludge. The tank contains 30,000 gallons $(\sim 1 \mathrm{ft})$ of heat generating sludge and 812,000 gallons $(\sim 25 \mathrm{ft})$ of supernatant (liquid waste). Figure 2.11 illustrates the tank waste contents of sludge and supernatant and the potential air flow paths of primary ventilation and secondary ventilation flows. The heat load has been estimated to be about 33,000 Btu/hr using thermal analysis (Sathyanarayana, 1996). 
HNF-SD-W030-ER-004 Rev. 0

Figure 2.6 Measured Tank 241-AY-101 Supernatant Temperature During August 1996 Through August 1997.

Tank AY-101 Supernatant Temperature at TE-69

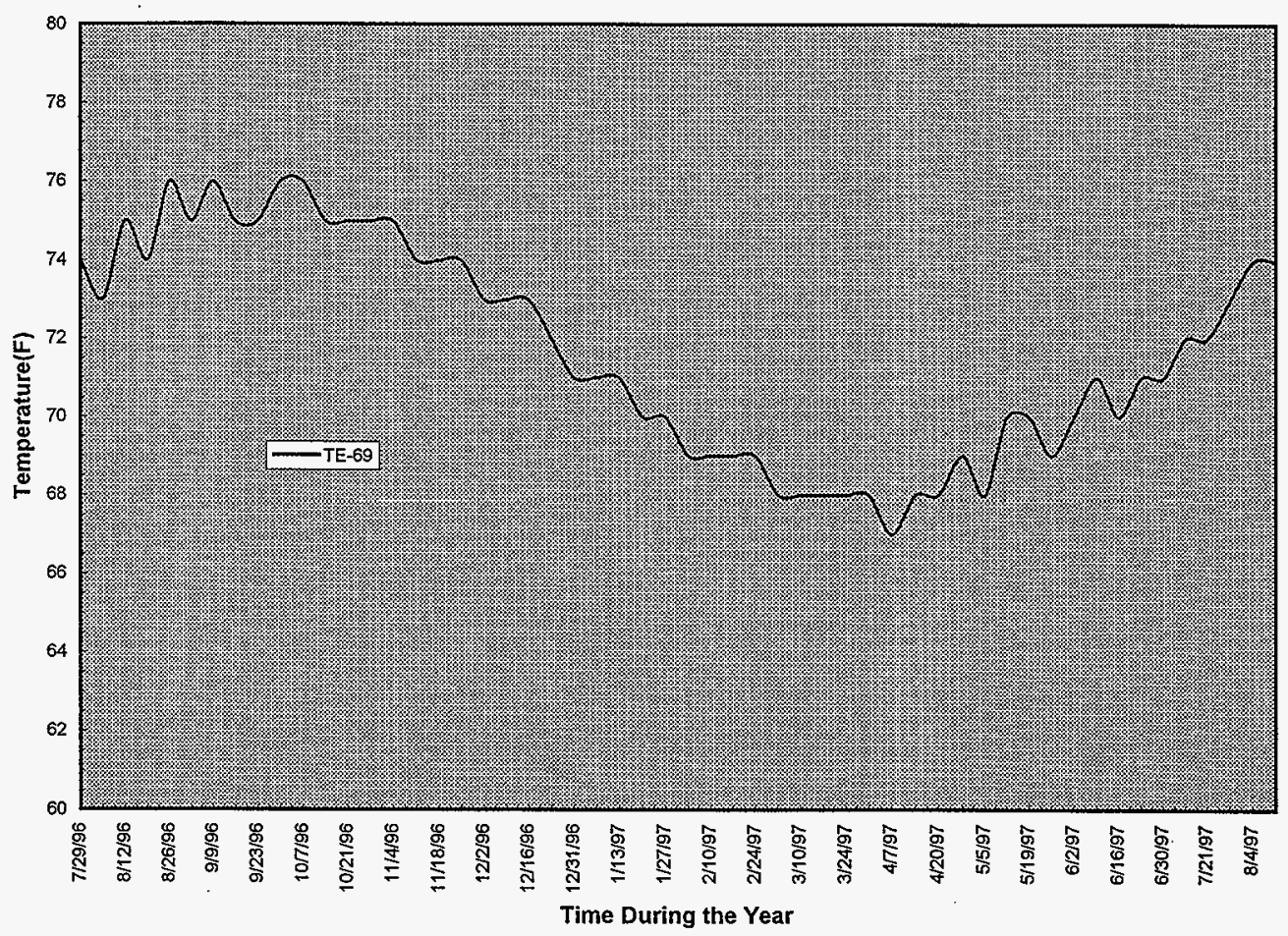




\section{HNF-SD-W030-ER-004 Rev. 0}

Figure 2.7 Measured Tank 241-AY-101 Waste Sludge Temperatures During May 1996 Through May 1997.

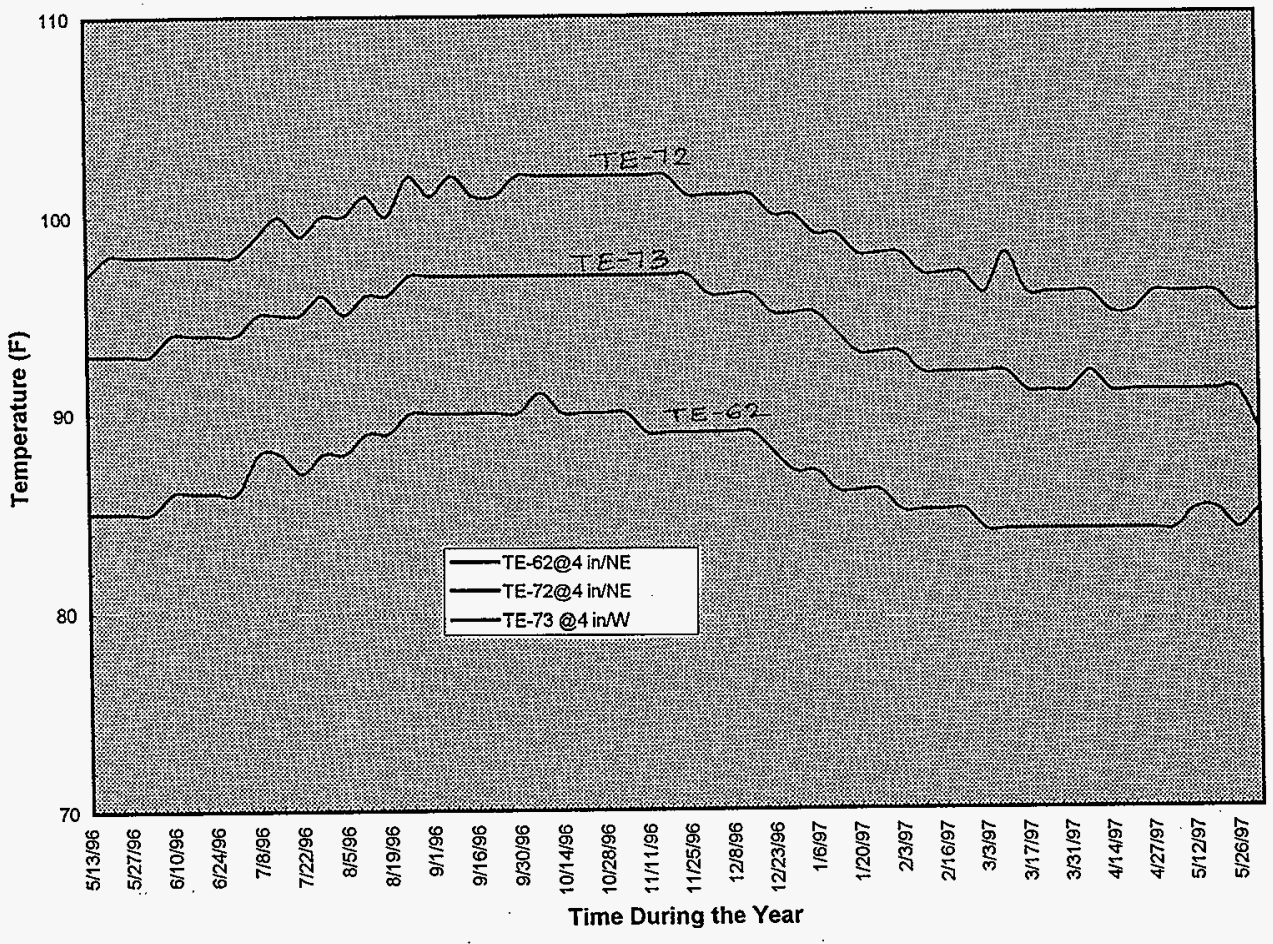


HNF-SD-W030-ER-004 Rev. 0

Figure 2.8 Measured Tank 241-AY-101 Waste Sludge Peak Temperature @ TC\#43 Attached to ALC\#4 During August 1996 Through August 1997.

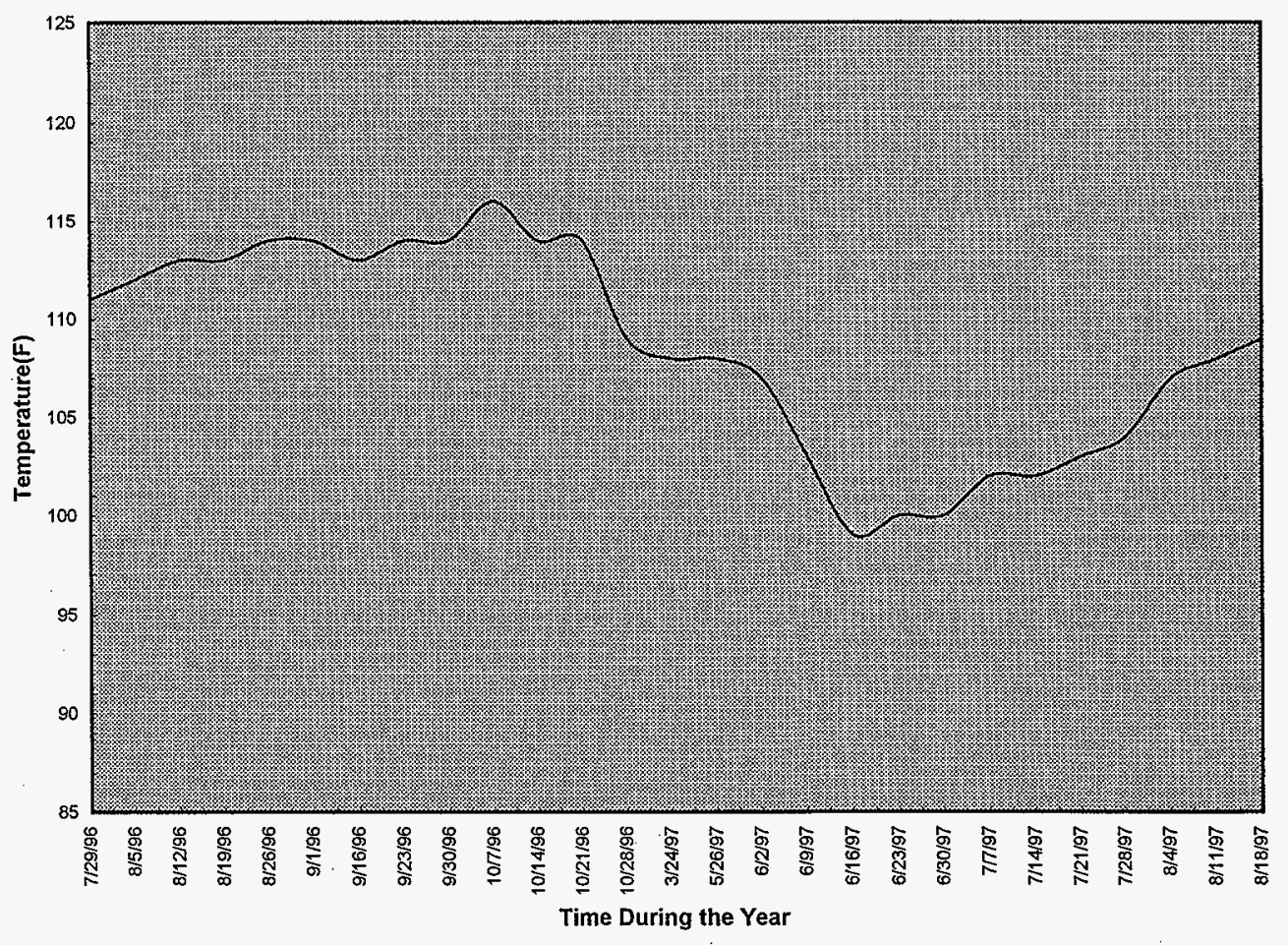


HNF-SD-W030-ER-004 Rev. 0

Figure 2.9 Tank 241-AY-101 Waste Level During April 1996 Through March 1997.

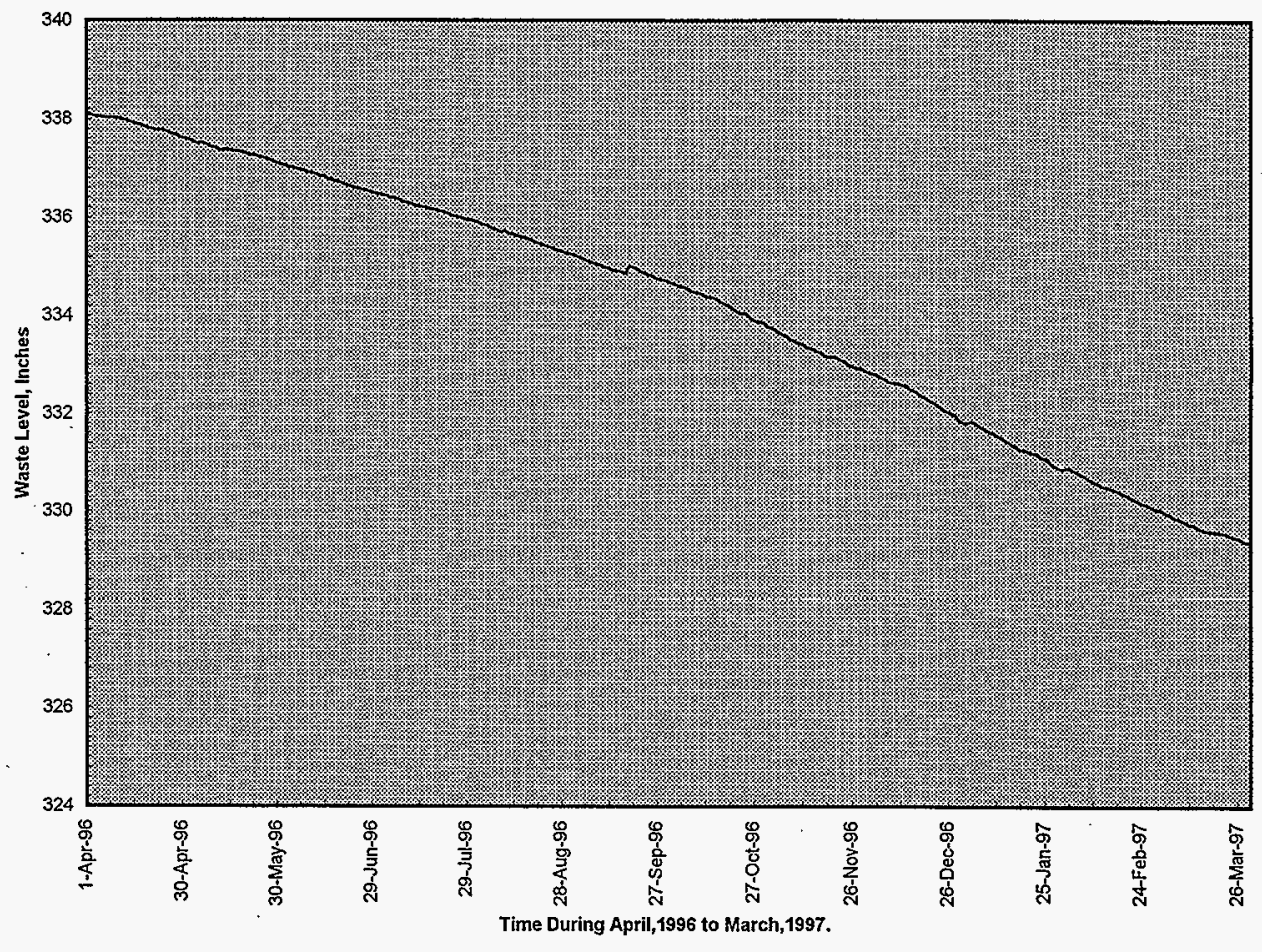


Figure 2.10 Tank 241-AY-102 Aging Waste Double-Shell Tank Design Details.

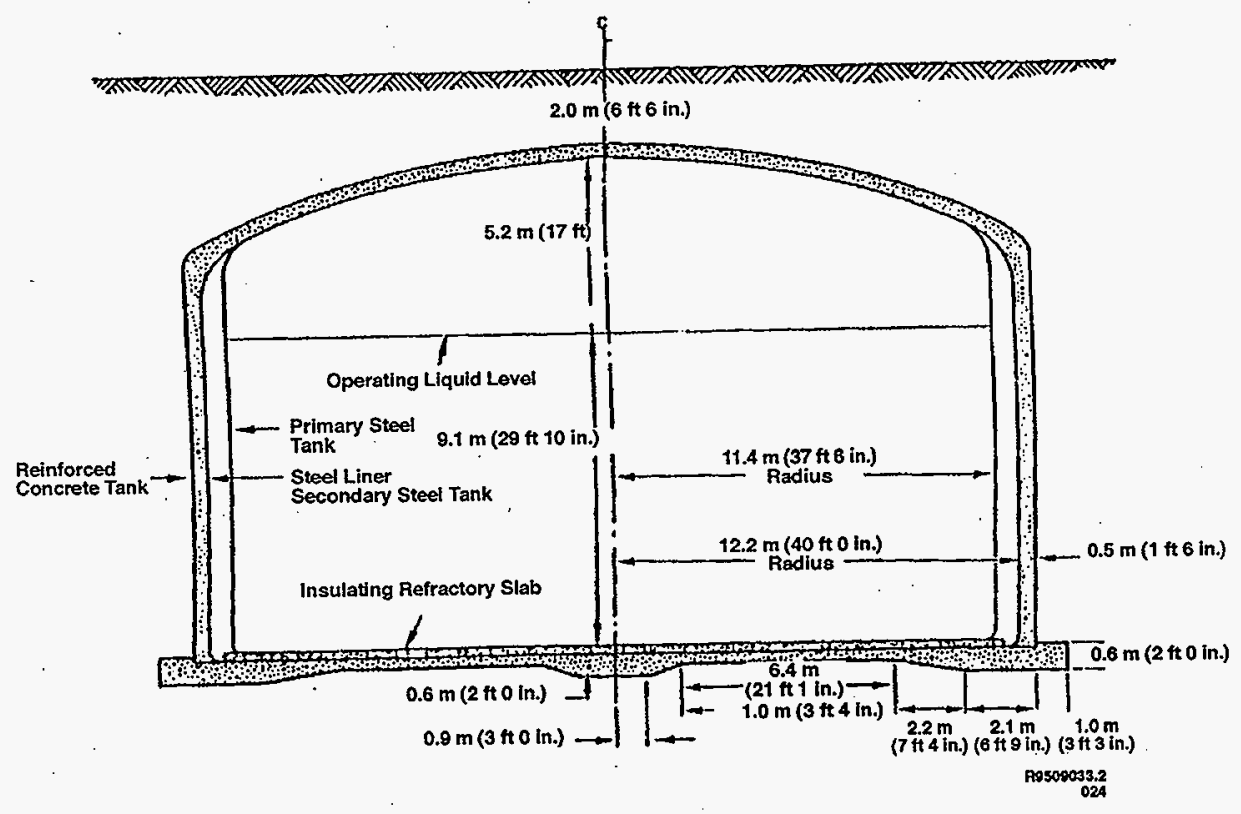




\section{HNF-SD-W030-ER-004 Rev. 0}

Figure 2.11 Tank 241-AY-102 Current Waste Sludge And Supernatant Levels and Potential Inleakage And Outlet Flow Paths For Primary And Secondary Ventilation Flow Paths.

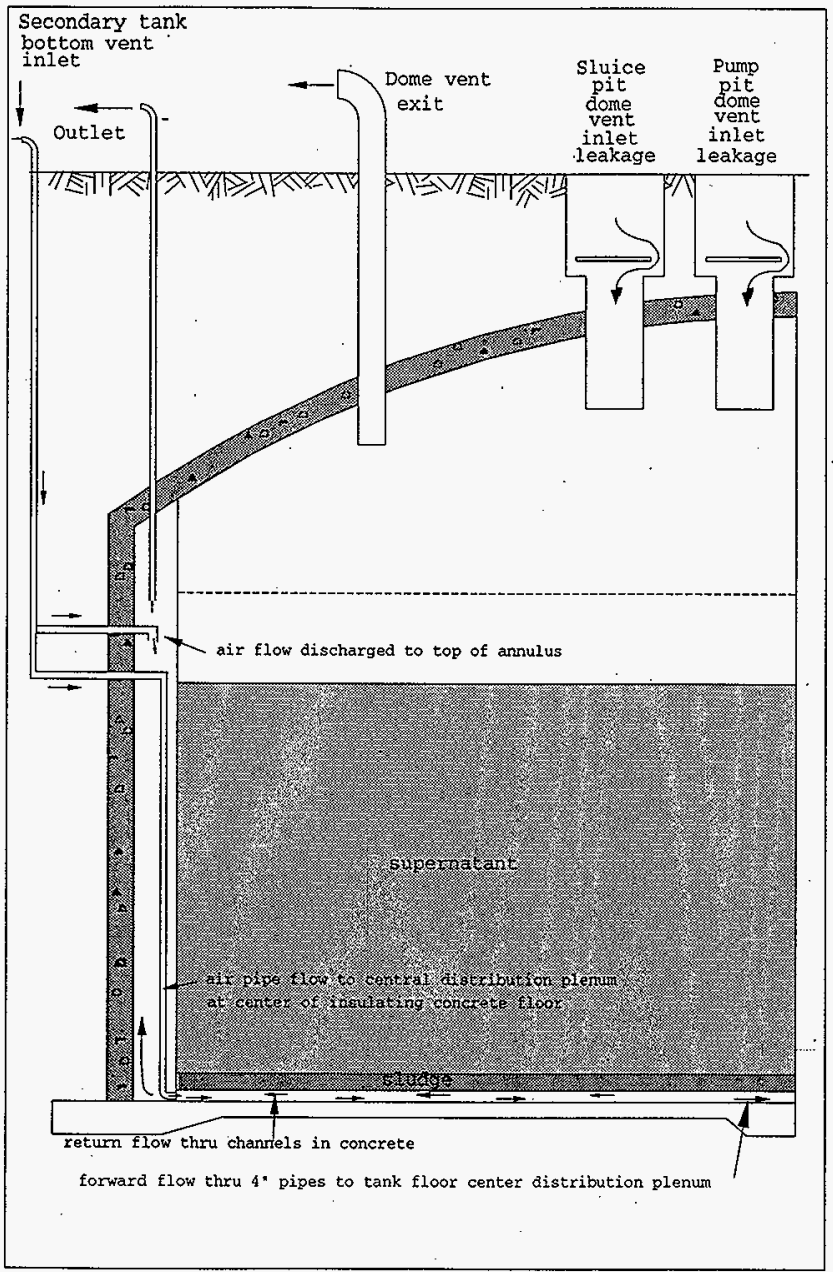


The maximum measured temperature of the sludge as shown in Figure 2.12 is about $88^{\circ} \mathrm{F}$ at thermocouple \#73 located 4 in. above tank bottom in west quadrant during September 1996. Also, the maximum supernatant temperature as shown in Figure 2.12 is about $76^{\circ} \mathrm{F}$ measured at thermocouple 69 located 300 in. above tank floor in Northeast quadrant during September 1996. The tank waste is currently cooled by evaporation and convective heat transfer from pool surface to the dome ventilation air, with minor heat removal by conduction through the soil to the atmosphere and ground water. The liquid evaporation rate determined from waste level data, shown in Figure 2.13, is 0.02 in/day during October, 96 to May, 97. However, during the rest of the year the evaporation rate will be higher as seen from the data for tank 241-AY-101.

$\& 2$

The secondary annulus/floor ventilation system has not been operated for several years but it was restarted on February 18, 1997. The total flow rate is believed to be around $1000 \mathrm{scfm}$. The secondary ventilation air is divided into two paths where one flow path leads to the annulus and the other path leads to floor channels. Since the flow path leading to the floor channels has much more flow resistance than the flow path leading to the annulus, more flow is expected to go directly to the annulus rather than to the annulus via the floor channels. For $1000 \mathrm{scfm}$ total annulus ventilation flow, the floor cooling channel will have about 160 scfm (Sathyanarayana, 1997). 


\section{HNF-SD-W030-ER-004 Rev. 0}

Figure 2.13 Measured Waste Supernatant Temperature For Tank 241-AY-102 During August 1996 Through August 1997.

Tank AY-102 Supernatant Temperature at TE-69

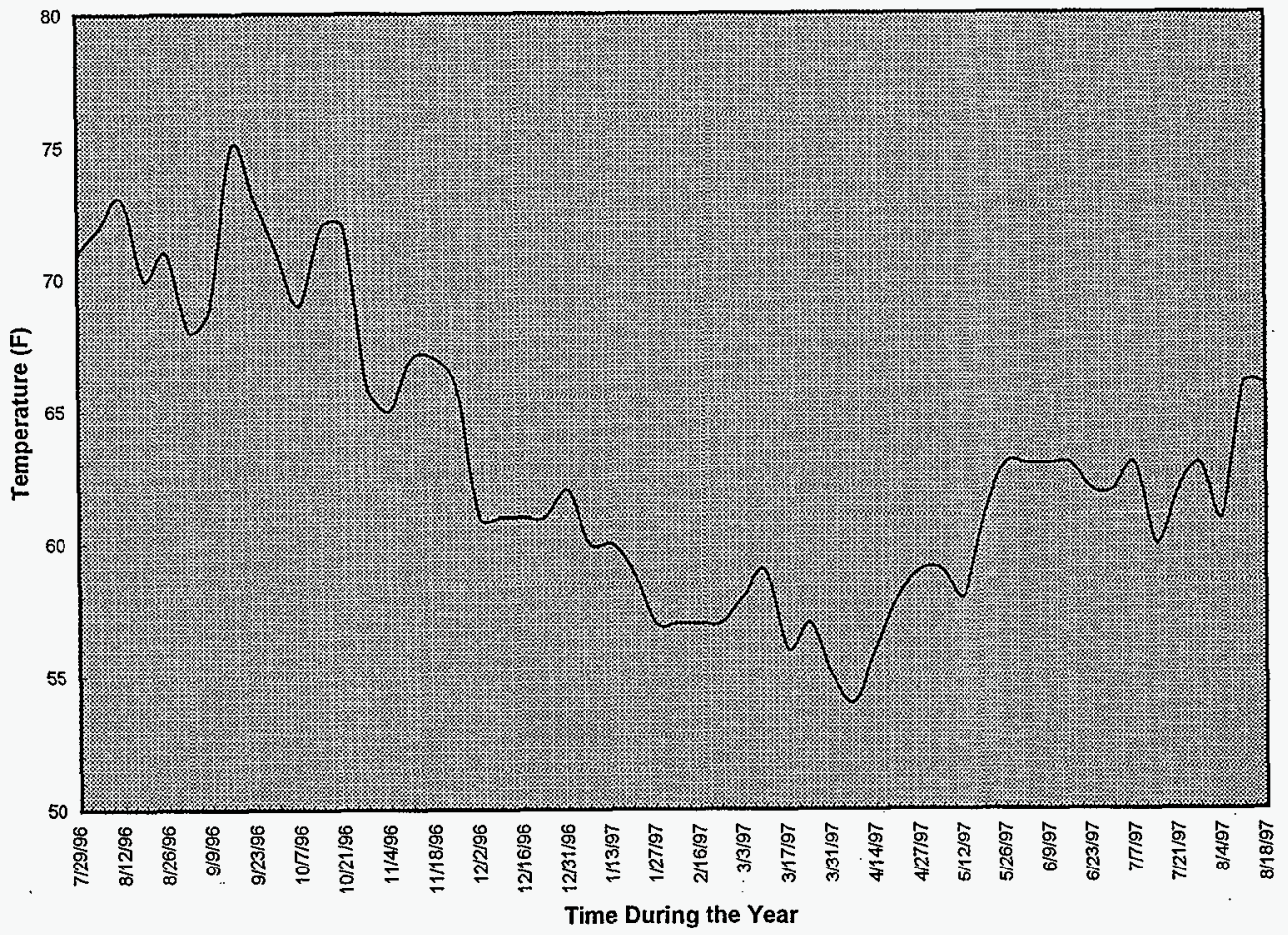




\section{HNF-SD-W030-ER-004 Rev. 0}

Figure 2.14 Measured Waste Level For Tank 241-AY-102 During May 1996 Through May 1997.

Tank AY-102 Waste Level

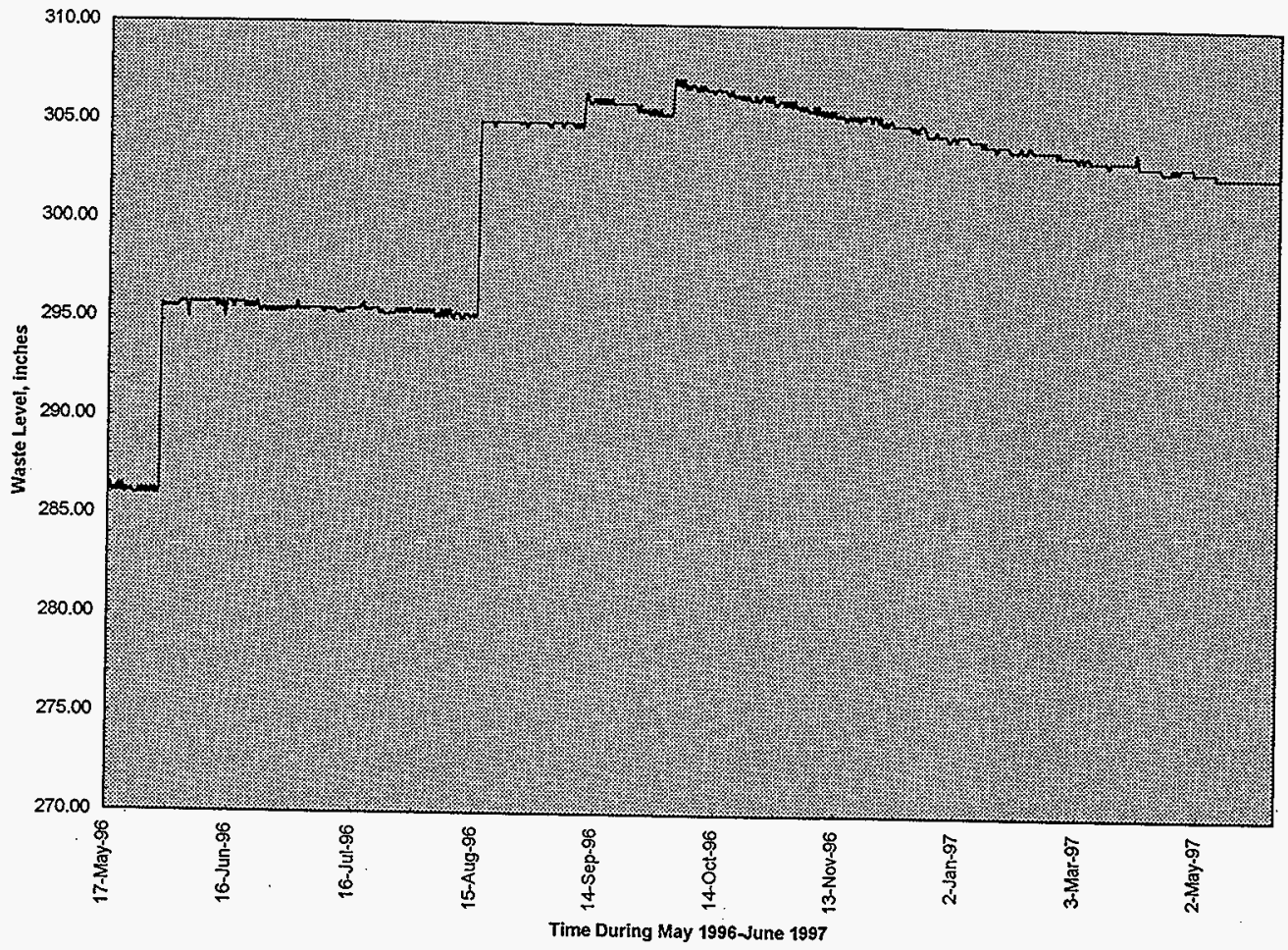




\subsection{W-030 Primary Ventilation System}

The ventilation systems for the aging waste tanks consist of the 702-A primary system, 702A backup ventilation system, 241-AY-101 tank annulus ventilation system, 241-AY-102 tank annulus ventilation system and combined 241-AZ-101 and 102 tank annuli ventilation system.

Under project W-030, a new upgraded primary ventilation system will be installed. The new system has been designed to accommodate the thermal load of mixer pumps of $402 \mathrm{KW}$ $(1.375 \mathrm{e}+06 \mathrm{Btu} / \mathrm{hr})$ in Tank 241-AZ-101. The new primary ventilation system for the four $\mathrm{AZ}$ and AY tanks is illustrated in Figure 3-1 contains individually controlled air inlet flows, independent closed loop cooling systems, and a common off gas exhaust system. The designed heat removal capacity is $488 \mathrm{KW}(1,666,000 \mathrm{Btu} / \mathrm{h})$ for tank AZ-101 and 264KW $(900,000 \mathrm{Btu} / \mathrm{h})$ for other AWF tanks, giving a total system heat removal capacity of $1280 \mathrm{KW}(4,366,000 \mathrm{Btu} / \mathrm{hr})$. The tank dome gases from each tank are exhausted through a flow control valve into a common exhaust stream and then cooled and filtered before being exhausted to the atmosphere through a stack.

The primary tank ventilation system will provide filtered inlet air for tank cooling and dilution for any flammable gases. The common exhaust stream draws enough air to maintain a negative pressure in the tank dome space of approximately one to three in. $\mathrm{H} 2 \mathrm{O}$ during normal operation. During normal operation, the system will supply approximately $100 \mathrm{scfm}$ of ambient air to the dome in addition to $400 \mathrm{scfm}$ from the recirculation loop at about $83^{\circ} \mathrm{F}$ and $100 \%$ relative humidity. The system operating in the recirculation mode will have less cooling capacity than the current operating system since the total air flow is reduced and air inlet conditions will be worse. However, the system provides secondary cooling-condensing of the off gas stream for tritium removal and removes particulate, condensible vapors, and iodine gas from the radioactive exhaust gases and exhausts the ventilation stream to the atmosphere through a HEPA filters to the stack. In addition to the recirculation mode, the system can also operate in bypass and high heat mode. The bypass mode supplies tank dome gases directly to the common exhaust system bypassing the Recirculation Cooling System. The different operating mode related air flow paths are schematically illustrated in Figures 3$2,3-3$, and 3-4. The high heat mode directs the tank dome gases through the Recirculation Cooling System and then into the common exhaust system with no air returning to the tank. Under the high heat mode of operation, the common exhaust fan flow will be increased and is expected to provide upto about $600 \mathrm{scfm}$. The flow from the high heat tank is routed through the Recirculation Cooling System to remove moisture. The W-030 system is not designed to provide $600 \mathrm{scfm}$ in a once through mode to all four tanks simultaneously. 
HNF-SD-W030-ER-004 Rev. 0

Figure 3.1 Schematic Diagram of 702-AZ (W-030) Primary Ventilation System.

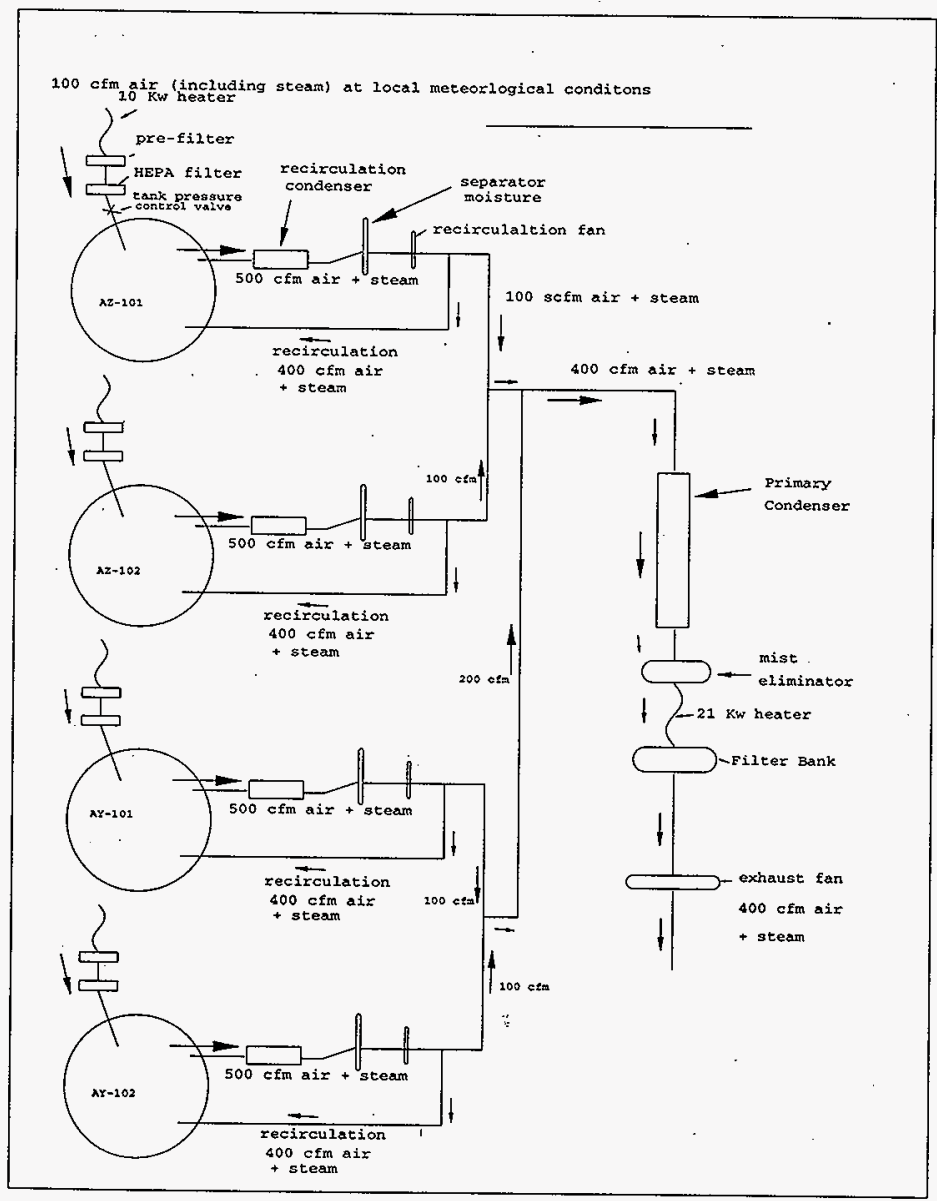


Figure 3.2 Air Flow Path For Recirculation Mode of Operation of 702-AZ (W-030) Ventilation System.

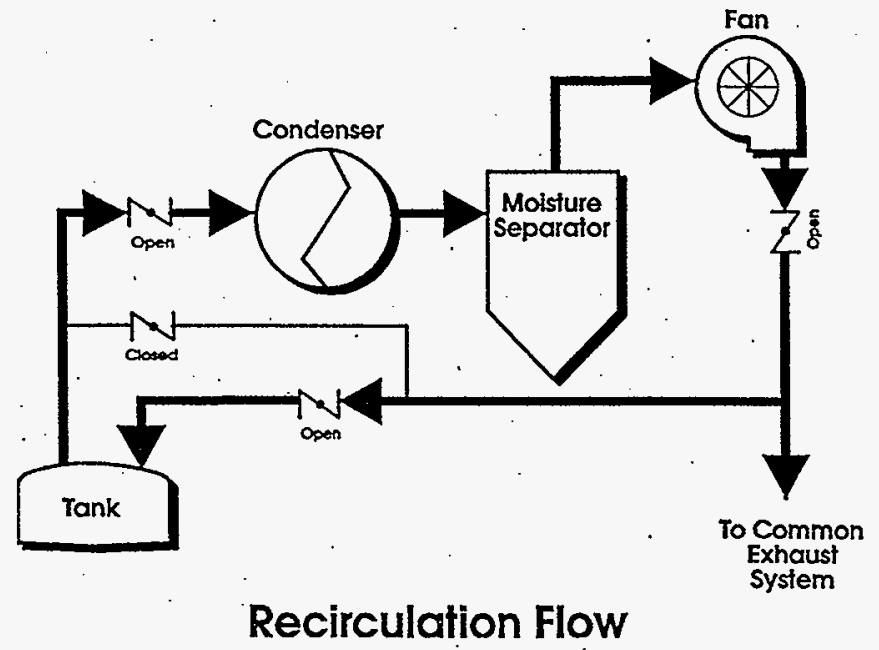


Figure 3.3 Air Flow Path For Bypass Mode of Operation of 702-AZ (W-030) Ventilation System.

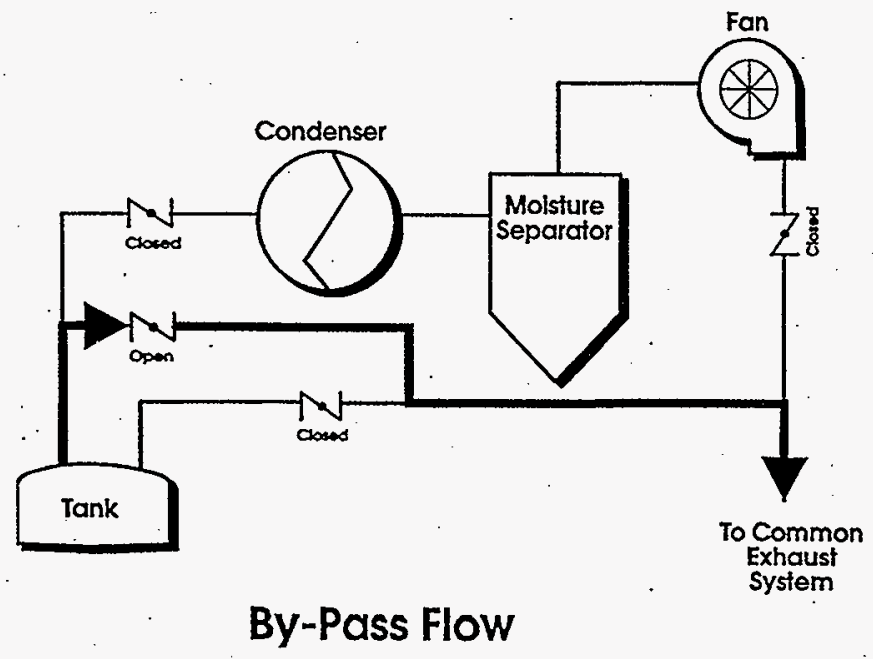


Figure 3.4 Air Flow Path For High Heat Mode of Operation of 702-AZ (W-030) Ventilation System.

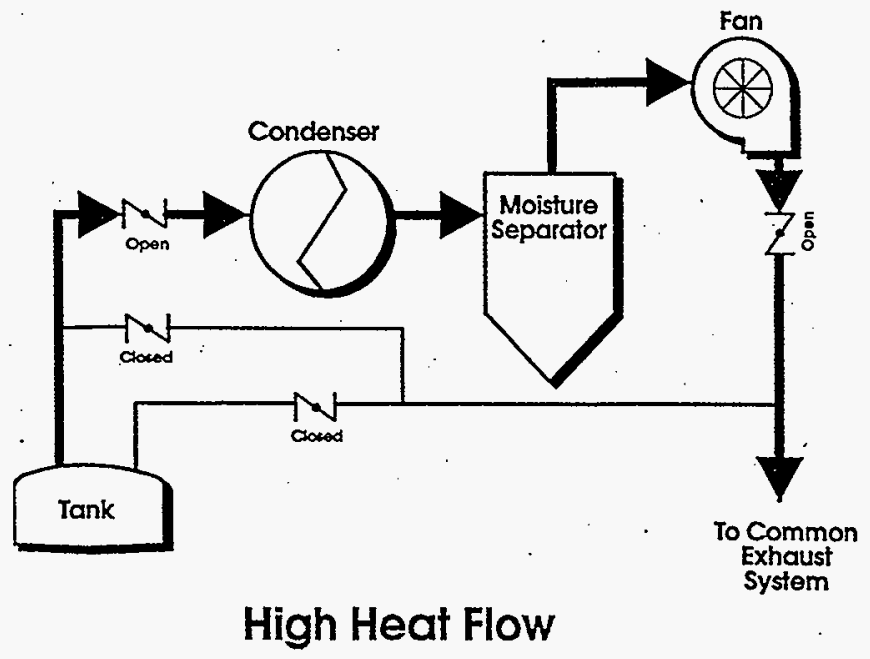


The bypass configuration at startup will vary from the designed configuration shown in Figure 3.3 in that only one connection will be made to the tank. This will be the normal return shown in Figure 3.2 and so the flow path in the bypass mode at startup will be out the normal return flow riser and then to the common exhaust duct of the ventilation system. The existing 241-A-702 primary ventilation system has design flow rates as high as 1000 scfm potential flow rate while W-030 system will have flow rates of $500 \mathrm{scfm}$ with $400 \mathrm{scfm}$ goes through the recirculation loop and only $100 \mathrm{scfm}$ ambient inleakage flow which will be exhausted to the stack. Basically the existing system has a designed heat removal capacity of 4 million Btu/hr per tank whereas the W-030 system has a designed cooling capacity of one million Btu/h for tanks AY-101, AY-102 and AZ-102 but for AZ-101 it has designed cooling capacity of 1.7 million $B t u / h r$. 


\section{4:0 Methodology and Assumptions}

This section briefly describes the methodology utilized and the assumptions used in the analysis. The methodology includes the description of the GOTH thermal hydraulic mode and the assumptions made in developing the model, the ambient inlet air flow temperature and humidity conditions to consider the effect of seasonal variation in sludge and supernatant temperatures and the waste parameters.

\subsection{GOTH Thermal Hydraulic Model}

The one dimensional GOTH thermal hydraulic model was used to consider the axial heat conduction in the sludge and tank dome soil. The model includes heat and mass transfer modeling at the pool surface to predict liquid evaporation. The model illustrated in Figure 4.1 is a derivative of prior analyses (Sathyanarayana, 1994) conducted for Tank 241-AZ-101. The sludge, supernatant, and dome gas space are modeled as separate volumes. The sludge volume is further subdivided into a number of axial nodes to represent the actual thickness of the sludge being considered. The annulus ventilation system is not considered in the analysis since it is not functioning for all the AWF tanks and also it will be conservative to use an adiabatic boundary condition. For given heat source of the waste in the tank, the predicted temperatures will be an upper bound. The primary ventilation flow inlet and outlet are modeled through appropriate junctions to the tank dome.

For the primary ventilation flow, the inlet air conditions assumed that ambient meteorological conditions correspond to a typical Hanford annual cycle. The data used corresponds to 1995 monthly averaged Hanford meteorological conditions. For the new primary ventilation system operating under recirculation mode of operation, the recirculation air was assumed to enter the tank dome at a constant flow rate and specified temperature and humidity conditions. Soil between the tank dome and the soil surface is also included in the model and the soil surface temperature is set to ambient meteorological conditions. Because of one dimensional nature of the model, no radial thermal gradients due to heat conduction to the soil below and surrounding the tank or due to annulus ventilation are included. Also, the azimuthal temperature gradients due to non-uniform cooling from the floor channels or nonuniform distribution of heat source in the sludge are considered negligible.

This general model is utilized for predicting the sludge temperatures in all the four AWF tanks. For each tank sludge parameters such as sludge and supernatant volumes and heat source values are considered and the peak sludge temperatures were predicted for different primary ventilation ambient flows as the recirculation modules for W-030 system will not be available during startup phase.

\footnotetext{
${ }^{1}$ GOTH is a trademark of JMI, which is derived from GOTHIC - a registered trademark of the EPRI Corp.
} 
Figure 4.1 GOTH Model For 1-D Heat Conduction in Sludge Waste and Liquid Waste Evaporation.

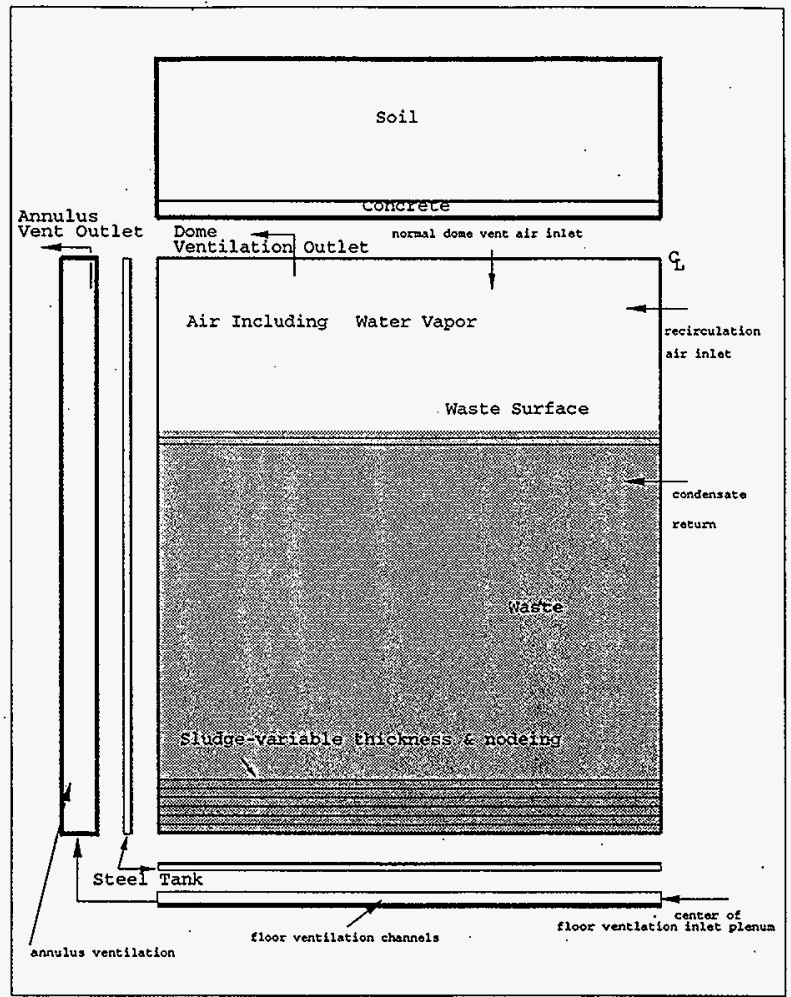




\subsection{Tank Ventilation Flow Inlet Conditions}

The summer average ambient conditions assumed were $70^{\circ} \mathrm{F}$ and $50 \%$ relative humidity. In this analysis annual meteorological data (Hoitink 1996) was used for the primary air inlet conditions to simulate the tank operations over a period of several years. The data consists of monthly average dry bulb temperature and relative humidity for a five year period as shown in Figures 4-2 and 4-3. Using the dry bulb temperature and relative humidity, the saturation pressure and the steam partial pressure in the air (i.e., the product of relative humidity and the saturation pressure corresponding to the dry bulb temperature) are computed and shown in Figure 4-4. The annual average for 1995 and the assumed summer average ambient conditions are also indicated in these figures. For evaluating the tank operation on a long term annual meteorological cycle basis, the air inlet annual cycle conditions were preceded by an assumed steady state continuous winter conditions of $32{ }^{\circ} \mathrm{F}$ and $75 \%$ relative humidity as shown in Figures 4-2 to 4-4 to achieve an approximate continuous winter steady state condition before proceeding with 5 annual cycles of typical monthly averaged meteorological data. This procedure has given nearly repetitive cyclic thermal hydraulic response after the first cycle.

\subsection{Tank Waste Parameters}

The waste parameters for AZ-101,AZ-102,AY-101 and AY-102 tank contents are discussed in this section. The parameters listed in Table 4.1 include the sludge and supernatant volumes, heat generation rates, sludge and supernatant density and sludge thermal conductivity. The dome top soil was assumed to have a thermal conductivity of $0.3 \mathrm{Btu} / \mathrm{hr}-$ $\mathrm{ft}-{ }^{\circ} \mathrm{R}$ and a specific heat of $0.22 \mathrm{Btu} / \mathrm{lbm}-^{\circ} \mathrm{R}$. The material properties such as thermal conductivity and specific heat for steel are assumed as $31 \mathrm{Btu} / \mathrm{hr}-\mathrm{ft}-{ }^{\circ} \mathrm{R}$ and $0.111 \mathrm{Btu} / \mathrm{lbm}-{ }^{\circ} \mathrm{R}$ and those for concrete as $0.54 \mathrm{Btu} / \mathrm{hr}-\mathrm{ft}-{ }^{\circ} \mathrm{R}$ and $0.21 \mathrm{Btu} / \mathrm{lbm}-{ }^{\circ} \mathrm{R}$ respectively. 
HNF-SD-W030-ER-004 Rev. 0

Table 4.1 AY/AZ Tank Farm Aging Waste Parameters

\begin{tabular}{|c|c|c|c|c|}
\hline Tank & 241-AZ-101 & 241-AZ-102 & 241-AY-101 & 241-AY-102 \\
\hline $\begin{array}{l}\text { Total Waste } \\
\text { Volume, kgal }\end{array}$ & 887 & 910 & 906 & 833 \\
\hline Sludge Volume, kgal & 35 & 95 & 94 & 30 \\
\hline $\begin{array}{l}\text { Supernatant } \\
\text { Volume, kgal }\end{array}$ & 852 & 815 & 812 & 803 \\
\hline Waste Level, in. & 322.5 & 330.9 & 329.5 & 302.9 \\
\hline $\begin{array}{l}\text { Maximum Sludge } \\
\text { Temperature, }{ }^{\circ} \mathrm{F}\end{array}$ & $\begin{array}{l}197^{\circ} \mathrm{F} @ \mathrm{TE}-46 \\
\text { October, } 1996\end{array}$ & $\begin{array}{l}187^{\circ} \mathrm{F} @ \text { TE-72 } \\
\text { October, } 1996\end{array}$ & $\begin{array}{l}116^{\circ} \mathrm{F} @ \mathrm{TE}-43 \\
\text { October, } 1996\end{array}$ & $\begin{array}{l}88^{\circ} \mathrm{F} @ \mathrm{TTE}-73 \\
\text { September, } 1996\end{array}$ \\
\hline $\begin{array}{l}\text { Maximum } \\
\text { Supernatant } \\
\text { Temperature, }{ }^{\circ} \mathrm{F} \\
\end{array}$ & $\begin{array}{l}153^{\circ} \mathrm{F} @ \text { TE-69 } \\
\text { October, } 1996\end{array}$ & $\begin{array}{l}134^{\circ} \mathrm{F} @ \text { TE-59 } \\
\text { October, } 1996\end{array}$ & $\begin{array}{l}76^{\circ} \mathrm{F} @ \text { @E-69 } \\
\text { October,1996 }\end{array}$ & $\begin{array}{l}76^{\circ} \mathrm{F} @ \text { TE-69 } \\
\text { September, } 1996\end{array}$ \\
\hline $\begin{array}{l}\text { Liquid Density, } \\
\mathrm{gm} / \mathrm{cm} 3\end{array}$ & 1.19 & 1.10 & 1.08 & 1.0 \\
\hline $\begin{array}{l}\text { Sludge Density, } \\
\mathrm{gm} / \mathrm{cm} 3\end{array}$ & 1.66 & 1.49 & 1.30 & 1.57 \\
\hline $\begin{array}{l}\text { Sludge Heat Rate, } \\
\text { Btu/hr }\end{array}$ & 152,000 & 129,000 & 41,000 & 33,000 \\
\hline $\begin{array}{l}\text { Supernatant Heat } \\
\text { Rate, Btu/hr }\end{array}$ & 89,600 & 64,600 & 0 & 0 \\
\hline $\begin{array}{l}\text { Specific Heat Rate } \\
\text { of Sludge, Btu/hr-ft3 }\end{array}$ & 32.49 & 10.16 & 3.263 & 8.229 \\
\hline $\begin{array}{l}\text { Specific Heat Rate } \\
\text { of Supernatant, } \\
\text { Btu/hr-ft3 }\end{array}$ & 0.7867 & 0.5929 & 0 & 0 \\
\hline Tank Heat Load & $241,600 \mathrm{Btu} / \mathrm{hr}$ & $193,600 \mathrm{Btu} / \mathrm{hr}$ & $41,000 \mathrm{Btu} / \mathrm{hr}$ & $33,000 \mathrm{Btu} / \mathrm{hr}$ \\
\hline
\end{tabular}


HNF-SD-W030-ER-004 Rev. 0

Figure 4.2 Monthly Average Ambient Temperatures For Five Annual Cycles.

ay101r9

Mon Sep 15 13:20:38 1997

GOTH Version 3.4 - April 1991

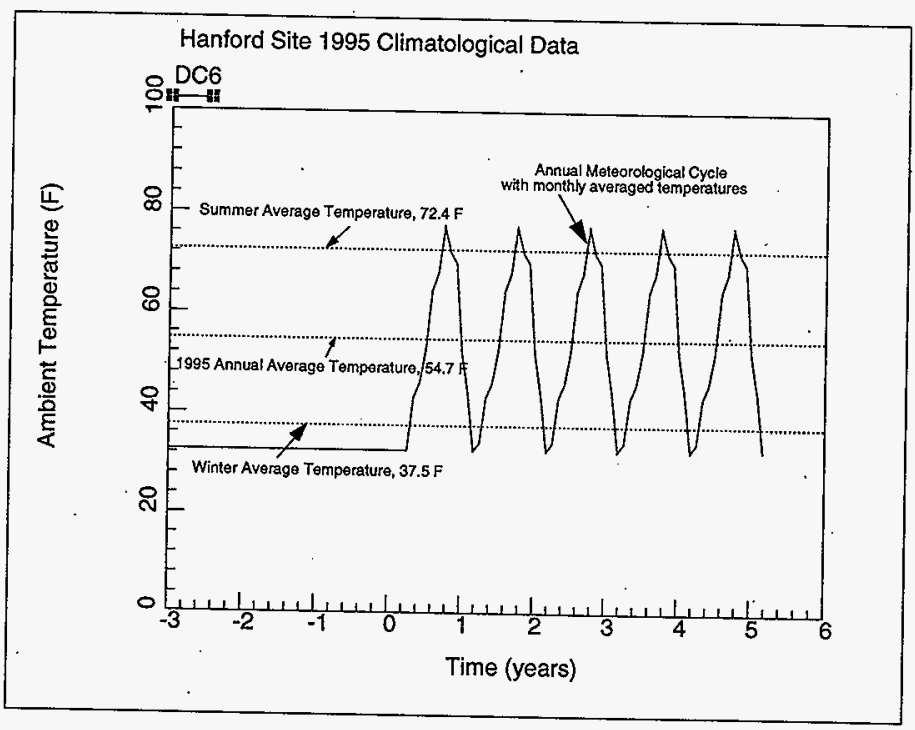


HNF-SD-W030-ER-004 Rev. 0

Figure 4.3 Monthly Average Ambient Relative Humidity For Five Annual Cycles.

ay101r9

Man Sep 15 13:20:28 1997

GOTH Version $3.4 \cdot$ April 1991

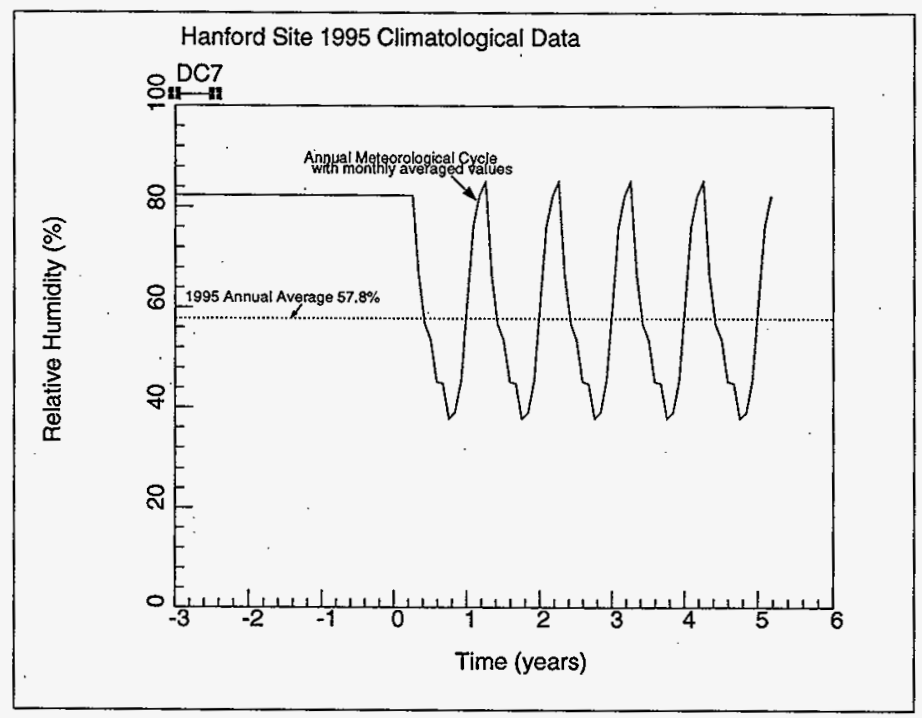


Figure 4.4 Monthly Average Ambient Saturation Pressure And Steam partial Pressure For Five Annual Cycles.

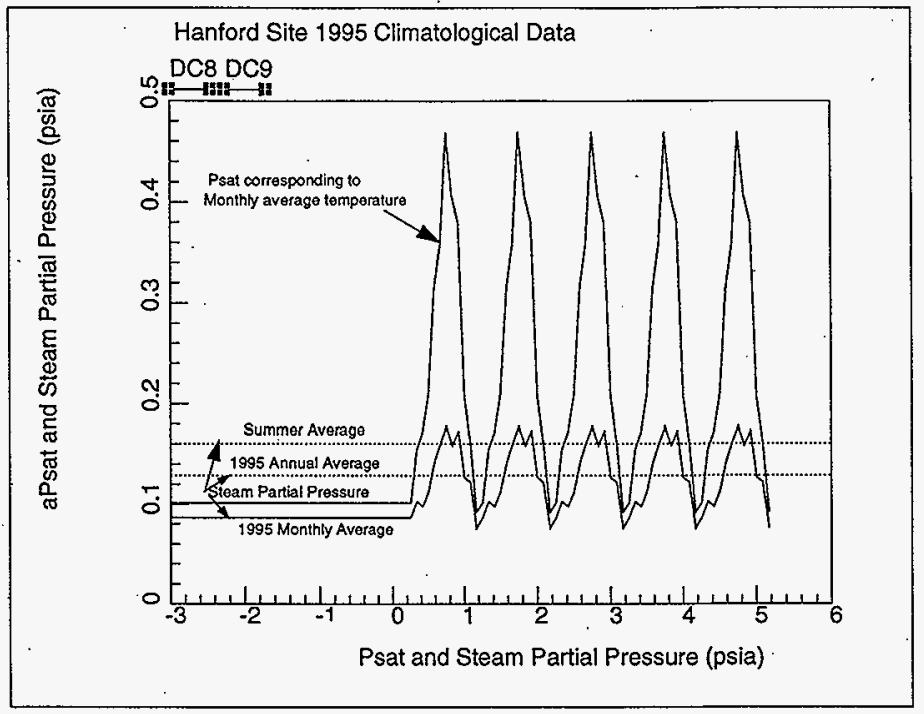




\subsection{Thermal Evaluation Results}

Thermal hydraulic evaluations were performed for each tank separately. Each primary ventilation flow rate considered was assumed to prevail for a long period in order to establish steady operating conditions.

\subsection{Tank 241-AZ-101}

The GOTH model (Figure 4.1) for the tank 241-AZ-101 with $1 \mathrm{ft}$ of sludge and $26 \mathrm{ft}$ of supernatant having heat sources of 32.49 and $0.7867 \mathrm{Btu} / \mathrm{hr}-\mathrm{ft} 3$ respectively was used with ambient air inlet flow conditions. The sludge thermal conductivity is assumed to be 0.42 $\mathrm{Btu} / \mathrm{hr}-\mathrm{ft}-{ }^{\circ} \mathrm{R}$. Annulus ventilation system is assumed to be not operating. First the waste temperatures were calculated to determine the operating conditions under W- 030 recirculation mode of operation. The ambient air conditions were those that correspond to 1995 monthly averaged Hanford meteorological conditions. The annual cycle conditions were preceded by an assumed steady state continuous winter conditions of $32^{\circ} \mathrm{F}$ and $75 \%$ relative humidity. The recirculation loop air is assumed to enter the tank at $83{ }^{\circ} \mathrm{F}$ and $100 \%$ relative humidity. Figure 5.1 shows the primary ventilation flow rates of ambient and recirculation loop tank inlet flows and tank outlet flow into exhaust duct. The results of the thermal hydraulic analysis shows that the peak sludge temperature of $194^{\circ} \mathrm{F}$ and supernatant temperature of $143^{\circ} \mathrm{F}$ (see Figure 5.2) which are close to the current operating range of temperatures. These waste temperatures are well below $30^{\circ} \mathrm{F}$ safety margin from local saturation temperatures. No effort was made to confirm the heat load considered in these calculations through thermal analysis. The heat load used is based on radioactive decay calculations using waste characterization data. The liquid evaporation rate is shown in Figure 5.3 and it can be seen that an annual average of about 0.225 in/day or $\sim 620$ gallons/day.

The thermal hydraulic calculations were performed for the tank using only ambient tank inlet flow at flow rates of $100,200,350$ and $400 \mathrm{scfm}$ and with no recirculation flow for the purpose of determining the minimum required flow to operate the tank safely under the bypass mode of operation. The results of these calculations are shown in Figures 5.4 through 5.7 and the peak sludge and supernatant temperatures summarized in Table 5.1. 


\section{HNF-SD-W030-ER-004 Rev. 0}

Figure 5.1 Tank 241-AZ-101 Primary Ventilation Inlet And Outlet Flows For W-030 System Operating in Recirculation Mode.

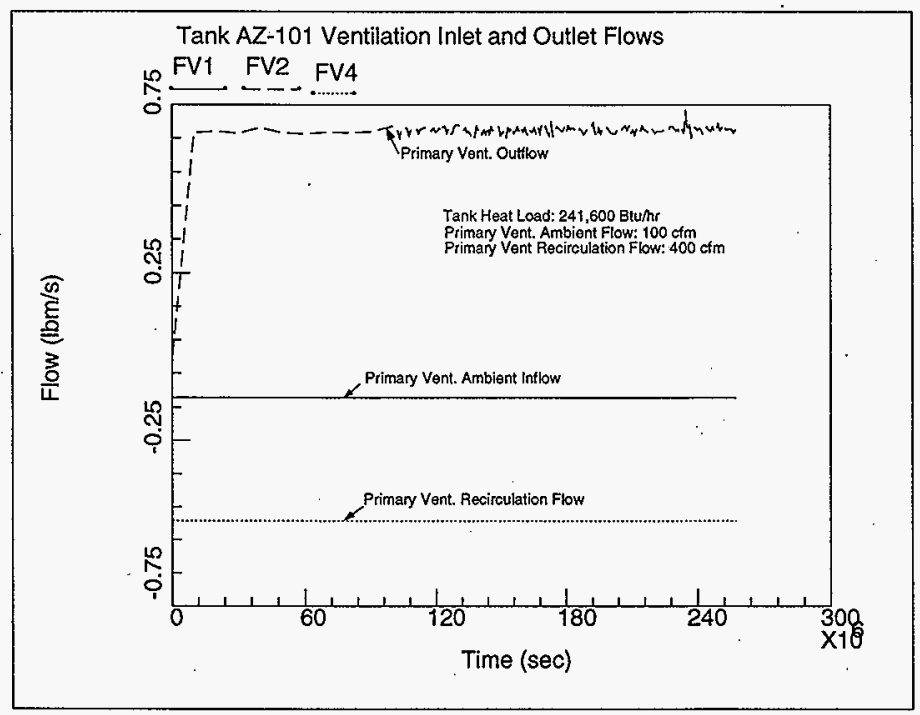


Figure 5.2 Tank 241-AZ-101 Waste Sludge and Supernatant Temperatures and Ventlation Flow Inlet and Outlet Temperatures For W-030 System Operating in Recirculation Mode.

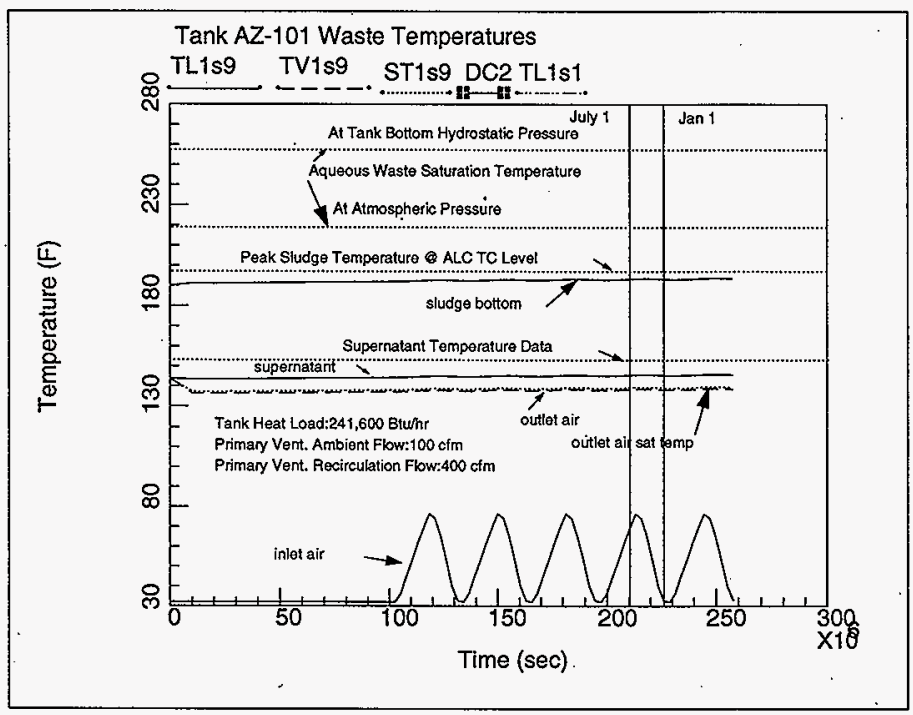


HNF-SD-W030-ER-004 Rev. 0

Figure 5.3 Tank 241-AZ-101 Liquid Waste Evaporation Rate For W-030 System Operating in Recirculation Mode.

az101r3no

Thu Sep 4 14:07:36 1997

GOTH Version 3.4 - April 1991

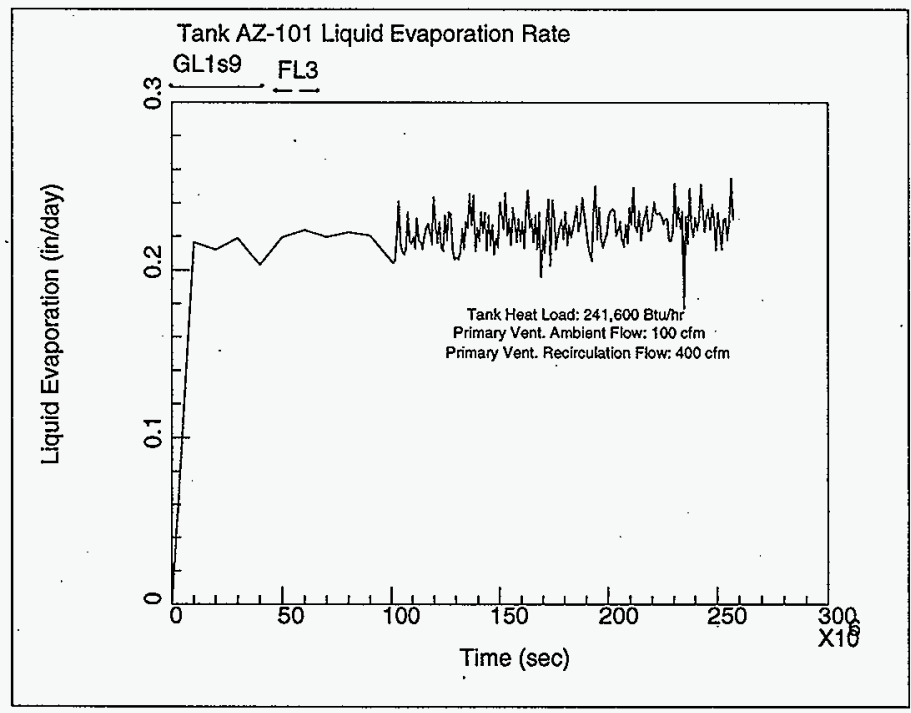


Figure 5.4 Tank 241-AZ-101 Waste Sludge and Supernatant Temperatures and Ventilation Flow Inlet and Outlet Temperatures For W-030 System Operating in Bypass

Mode With $100 \mathrm{scfm}$ Ambient Inleakage Flow.

azio1r3n4

Tue Sep 2 16:50:19 1997

GOTH Version 3.4 - April 1991

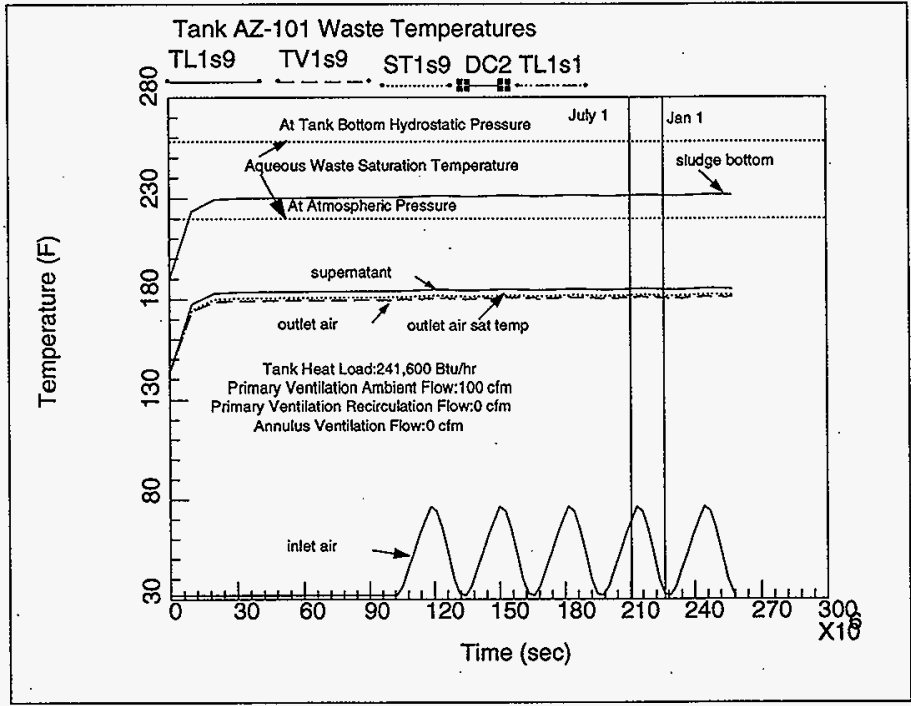


Figure 5.5 Tank 241-AZ-101 Waste Sludge and Supernatant Temperatures and Ventilation Flow Inlet and Outlet Temperatures For W-030 System Operating in Bypass

Mode With 200 scfm Ambient Inleakage Flow.

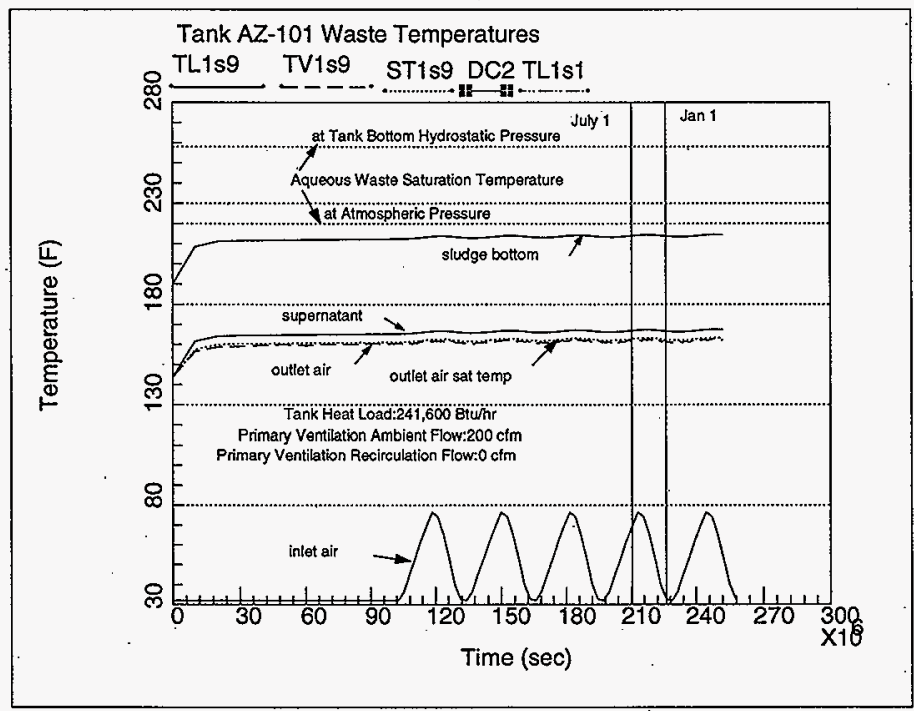


Figure 5.6 Tank 241-AZ-101 Waste Sludge and Supernatant Temperatures and Ventilation Flow Inlet and Outlet Temperatures For W-030 System Operating in Bypass Mode With 350 scfm Ambient Inleakage Flow.

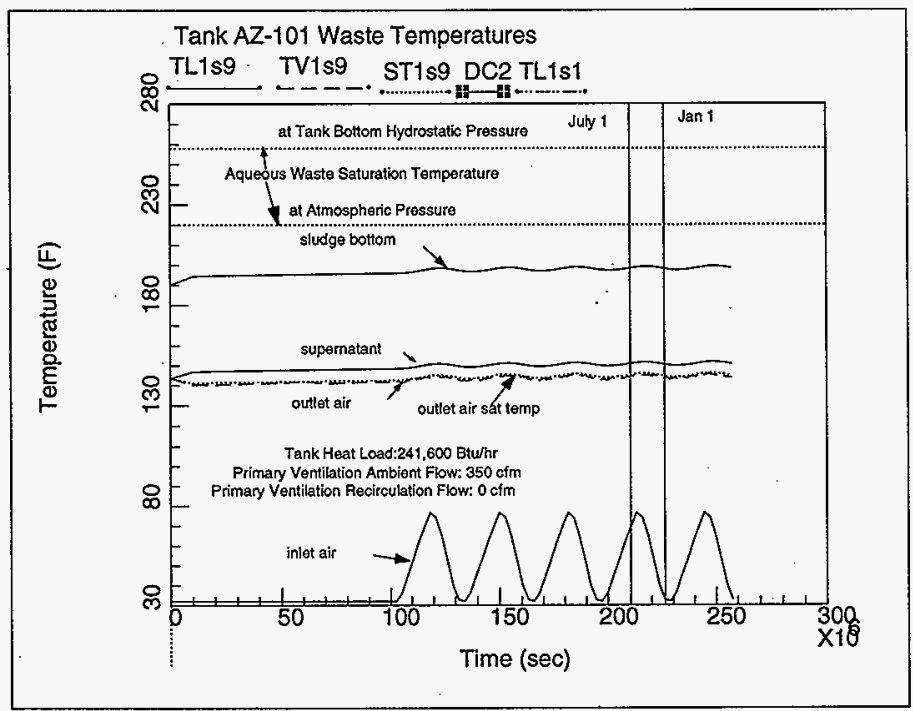


Figure 5.7 Tank 241-AZ-101 Waste Sludge and Supernatant Temperatures and Ventilation Flow Inlet and Outlet Temperatures For W-030 System Operating in Bypass Mode With 400 scfm Ambient Inleakage Flow.

az101r3n2

Tue Sep 2 16:13:18 1997

GOTH Version 3.4 - April 1991

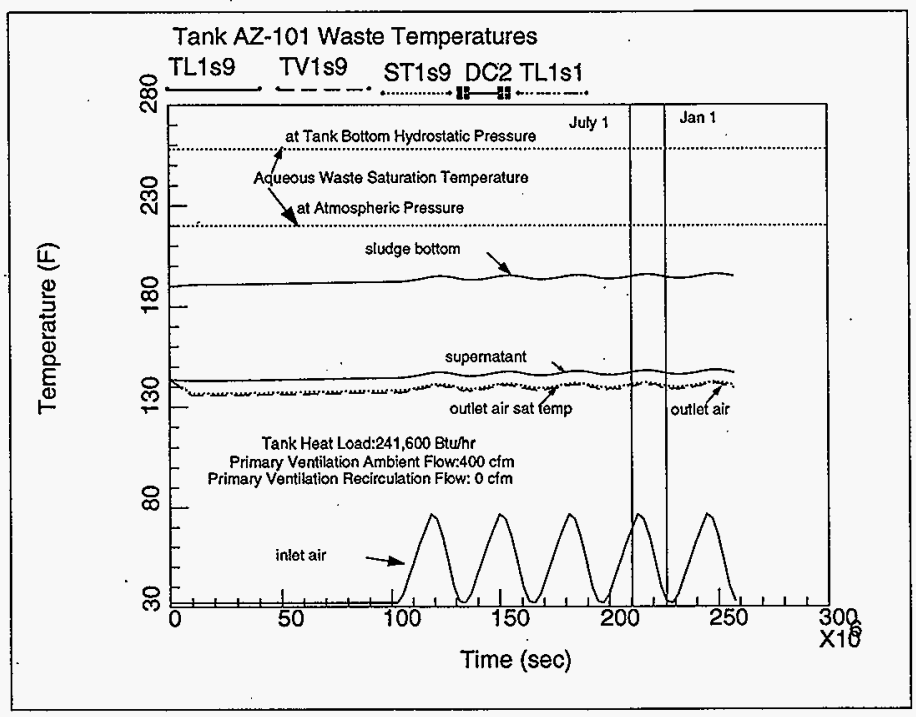


Table 5.1 Tank 241-AZ-101 Waste Temperatures For Different Primary Ventilation Flows

\begin{tabular}{|l|l|l|l|}
\hline $\begin{array}{l}\text { Primary } \\
\text { Ventilation } \\
\text { Ambient Flow, } \\
\text { scfm }\end{array}$ & $\begin{array}{l}\text { Primary } \\
\text { Ventilation } \\
\text { Recirculation } \\
\text { Flow, scfm }\end{array}$ & $\begin{array}{l}\text { Sludge Peak } \\
\text { Temperature, } \\
{ }^{\circ} \mathrm{F}\end{array}$ & $\begin{array}{l}\text { Supernatant } \\
\text { Peak } \\
\text { Temperature, } \\
{ }^{\circ} \mathrm{F}\end{array}$ \\
\hline 100 & 400 & 194 & 143 \\
\hline 100 & 0 & 232 & 185 \\
\hline 200 & 0 & 215 & 165 \\
\hline 350 & 0 & 200 & 150 \\
\hline 400 & 0 & 196 & 146 \\
\hline
\end{tabular}

The results show that the tank under current heat load conditions can be operated safely only if the primary ventilation ambient inflow is maintained at more than $200 \mathrm{scfm}$.

\subsection{Tank 241-AZ-102}

GOTH model for the tank $241-\mathrm{AZ}-102$ has 3 feet of sludge with a density of $1.49 \mathrm{gm} / \mathrm{cm} 3$ and $24.5 \mathrm{ft}$ of supernatant with a density of $1.1 \mathrm{gm} / \mathrm{cm} 3$. It has heat sources of 10.16 and $0.5929 \mathrm{Btu} / \mathrm{hr}-\mathrm{ft} 3$ respectively. The sludge thermal conductivity of $0.42 \mathrm{Btu} / \mathrm{hr}-\mathrm{ft}-{ }^{\circ} \mathrm{R}$ was used. The annulus ventilation system was not operating. First calculation assumes that W030 system will operate in recirculation mode supplying $100 \mathrm{scfm}$ ambient inleakage air flow and $400 \mathrm{scfm}$ recirculation air flow to the tank. The ambient air conditions of temperature, and humidity used correspond to 1995 monthly averaged Hanford meteorological conditions. The recirculation air flow enters the tank at $83{ }^{\circ} \mathrm{F}$ and $100 \%$.relative humidity. The annual cycle conditions were preceded by assumed average winter conditions of $32{ }^{\circ} \mathrm{F}$ and $100 \%$ relative humidity to achieve approximate winter steady state conditions before proceeding with five annual cycles. The procedure results in nearly repetitive cyclic thermal hydraulic response after the first cycle.

The primary ventilation ambient inleakage flow, recirculation flow and dome outlet flows are shown in Figure 5.8. The peak sludge and supernatant temperatures, dome gas outlet temperature and outlet air saturation temperature as well as ambient air inlet temperature are shown in Figure 5.9. The sludge and supernatant have reached a peak temperature of 
HNF-SD-W030-ER-004 Rev. 0

Figure 5.8 Tank 241-AZ-102 Primary Ventilation Inlet And Outlet Flows For W-030 System - Operating in Rewcirculation Mode.

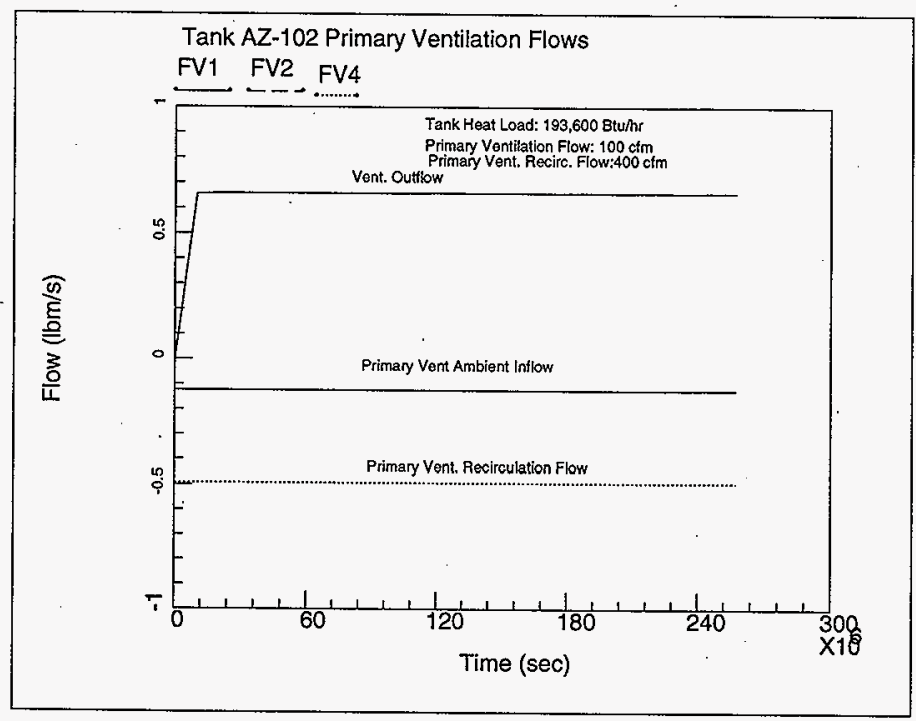




\section{HNF-SD-W030-ER-004 Rev. 0}

Figure 5.9 Tank 241-AZ-102 Waste Sludge and Supernatant Temperatures and Ventilation Flow Inlet and Outlet Temperatures For W-030 System Operating in Recirculation Mode.

az102r3no

Tue Sep 2 22:02:41 1997

GOTH Version 3.4 - April 1991

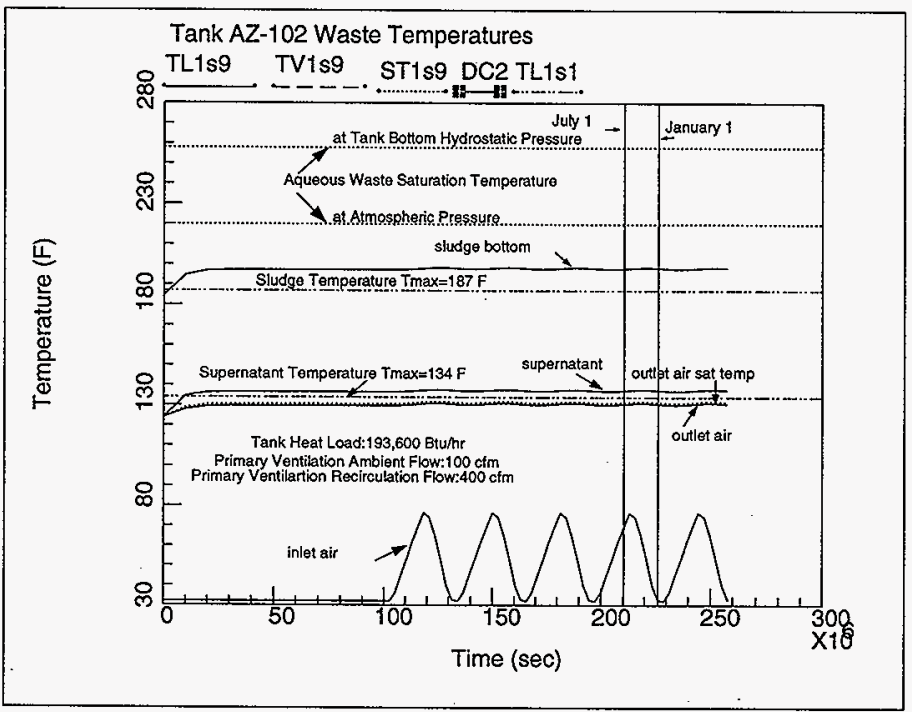




\section{HNF-SD-W030-ER-004 Rev. 0 、}

$198^{\circ} \mathrm{F}$ and $137{ }^{\circ} \mathrm{F}$ respectively. These values are higher than the current operating temperatures. But currently the tank is being supplied around 550 to $580 \mathrm{cfm}$. Therefore these higher temperatures should be expected. These waste temperatures are below a $30^{\circ} \mathrm{F}$ safety margin from local saturation temperatures. In this case also no attempt is made to confirm the heat load value which is based on radioactive decay. The liquid evaporation rate is shown in Figure 5.10 and it shows that the annual average evaporation rate of 0.171 in/day ( $\sim 470$ gallons/day).

For the purpose of determining the minimum inleakage flow requirement during start-up of W-030 system, several thermal hydraulic calculations with ambient flow as a parameter are performed. The ambient inleakage flows considered are 100,200,350 and $400 \mathrm{scfm}$. Also for $350 \mathrm{scfm}$ ambient flow case, two more calculations were performed to assess the effect of higher heat load. The characterization report value is $199,500 \mathrm{Btu} / \mathrm{hr}$ which is slightly higher than the value used in these calculations. The other heat load value considered is $209,000 \mathrm{Btu} / \mathrm{hr}$. The results of these calculations for waste temperatures are shown in Figures 5.11 through 5.17 and the peak temperatures for the sludge and supernatant are summarized in Table 5.2. . For the tank 241-AZ-102 also the primary inleakge flow should be more than $200 \mathrm{scfm}$ in order to operate the tank within the safety limits. Based on the data from the analysis, it can be seen that $350 \mathrm{scfm}$ flow will provide adequate safety margin for the waste temperatures even if the heat load of the tank is $209,000 \mathrm{Btu} / \mathrm{hr}$. Using the tank beat load of $209,000 \mathrm{Btu} / \mathrm{hr}$ with $550 \mathrm{scfm}$ ambient inleakage flow which is close to the current operating condition, shows that the peak supernatant and sludge temperature are closer to the measured temperature data. 
Figure 5.10 Tank 241-AZ-102 Liquid Waste Evaporation Rate For W-030 System Operating in Recirculation Mode.

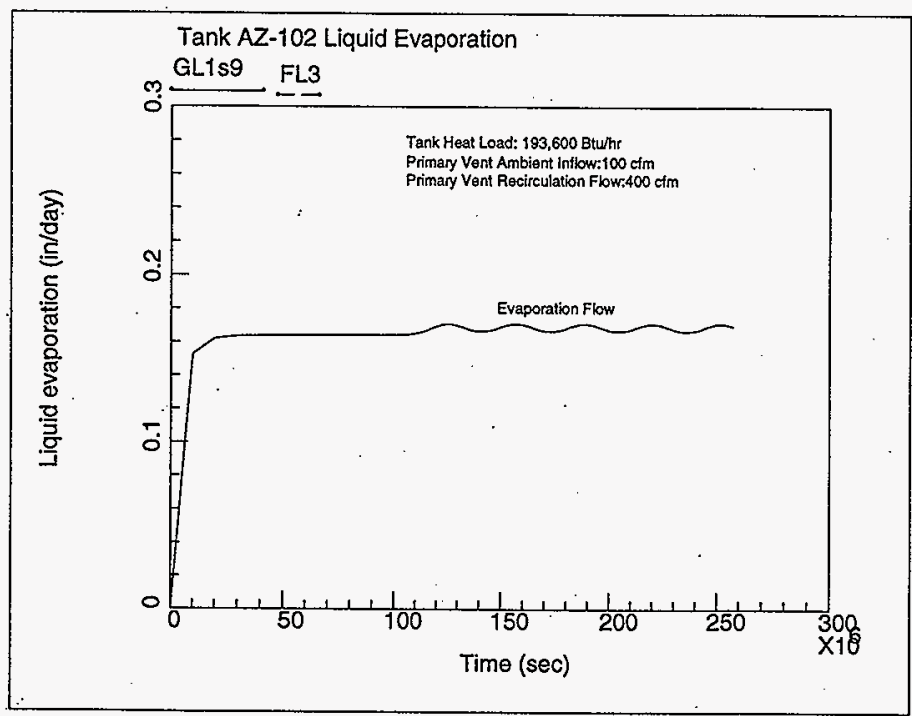


Figure 5.11 Tank 241-AZ-102 Waste Sludge and Supernatant Temperatures and Ventilation Flow Inlet and Outlet Temperatures For W-030 System Operating in Bypass Mode With $100 \mathrm{scfm}$ Ambient Inleakage Flow.

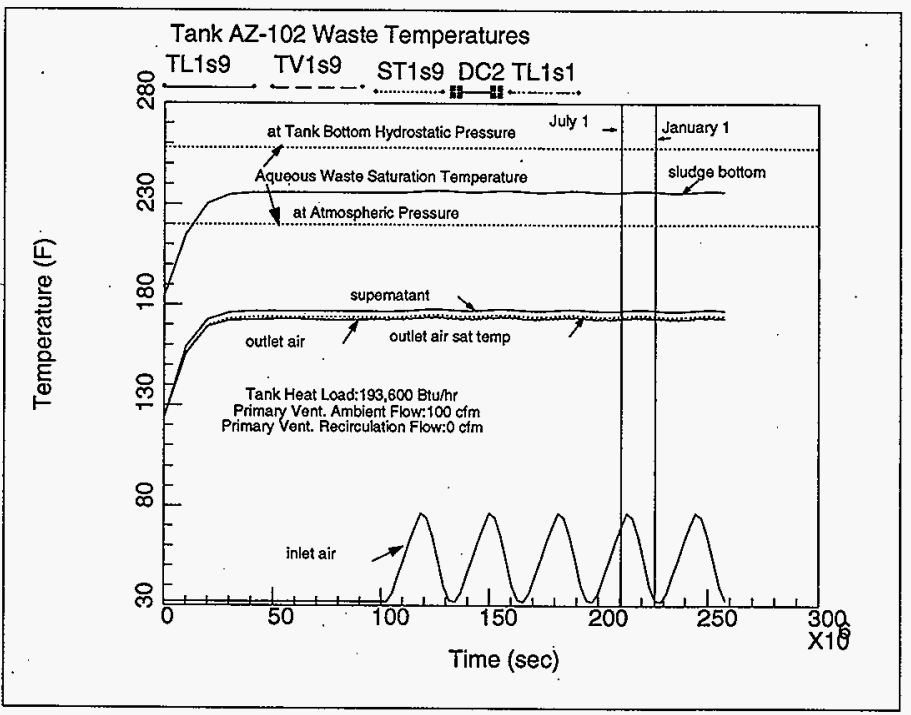




\section{HNF-SD-W030-ER-004 Rev. 0}

Figure 5.12 Tank 241-AZ-102 Waste Sludge and Supernatant Temperatures and Ventilation Flow Inlet and Outlet Temperatures For W-030 System Operating in Bypass Mode With $200 \mathrm{scfm}$ Ambient Inleakage Flow.

az102r3n3

Tue Sep 2 22:25:33 1997

GOTH Version 3.4 - April 1991

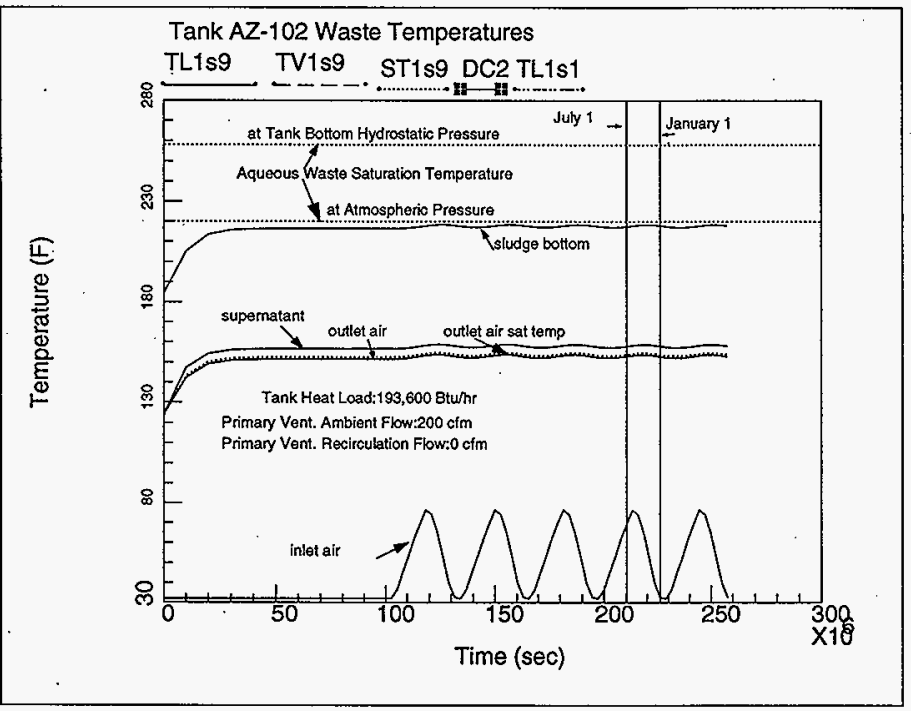


Figure 5.13 Tank 241-AZ-102 Waste Sludge and Supernatant Temperatures and Ventilation Flow Inlet and Outlet Temperatures For W-030 System Operating in Bypass Mode With $350 \mathrm{scfm}$ Ambient Inleakage Flow.

azio2r3n5

Tue Sep 2 22:40:44 1997

GOTH Version 3.4 - April 1991

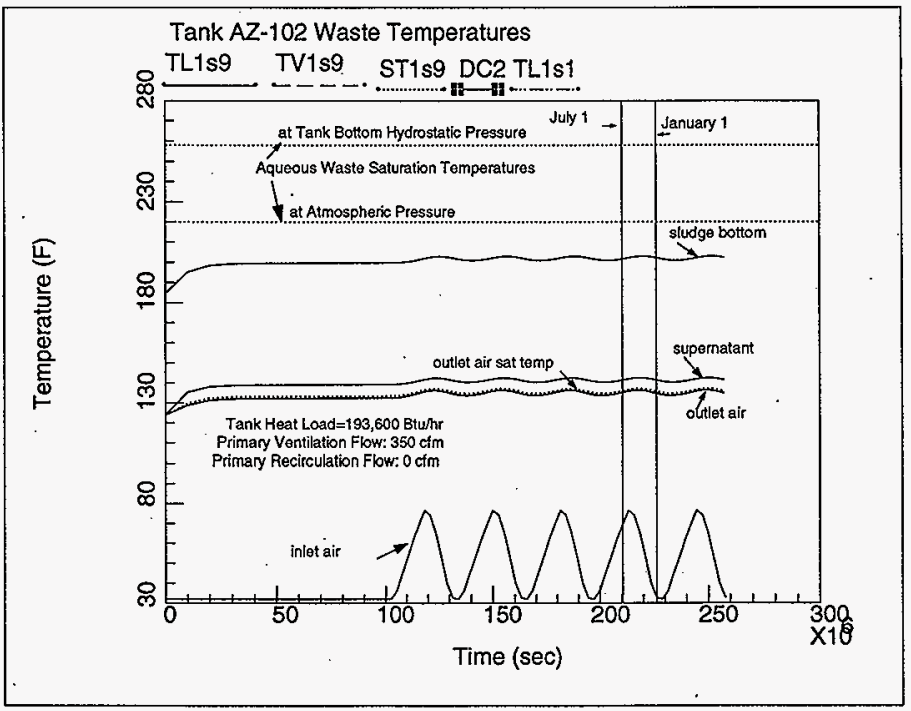


Figure 5.14 Tank 241-AZ-102 Waste Sludge and Supernatant Temperatures and Ventilation Flow Inlet and Outlet Temperatures For W-030 System Operating in Bypass Mode With 400 scfm Ambient Inleakage Flow.

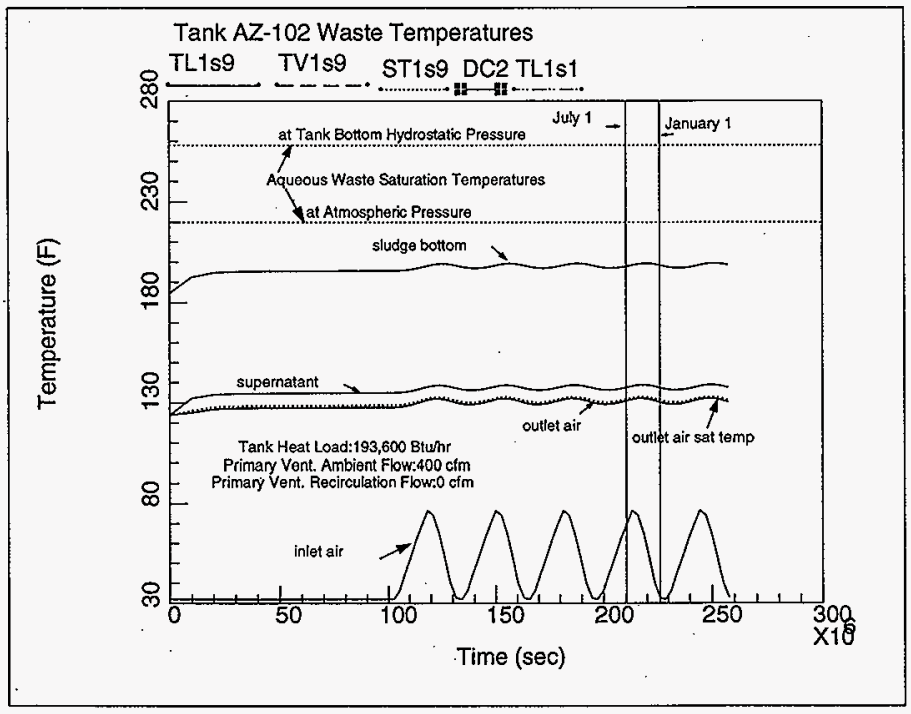


Figure 5.15 Tank 241-AZ-102 Waste Sludge and Supernatant Temperatures and Ventilation Flow Inlet and Outlet Temperatures For W-030 System Operating in Bypass Mode With $350 \mathrm{scfm}$ Ambient Inleakage Flow and Heat Load of 199,500 Btu/hr.

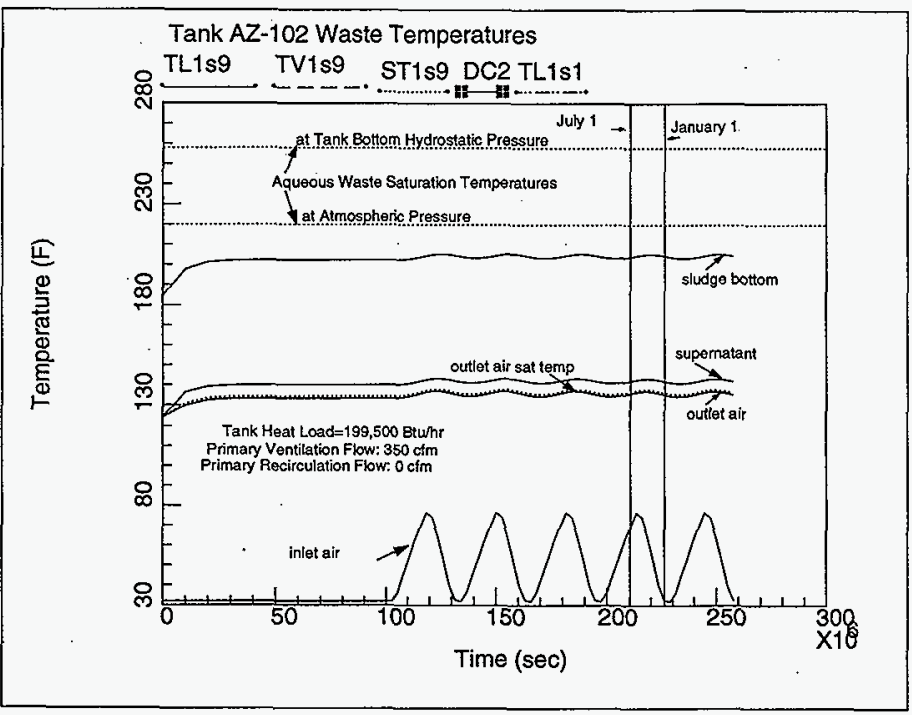


Figure 5.16 Tank 241-AZ-102 Waste Sludge and Supernatant Temperatures and Ventilation Flow Inlet and Outlet Temperatures For W-030 System Operating in Bypass Mode With 350 scfm Ambient Inleakage Flow and Heat Load of 209,000 Btu/hr.

az102r3n7

Tue Sep 2 23:16:25 1997

GOTH Version 3.4 - Aptil 1991

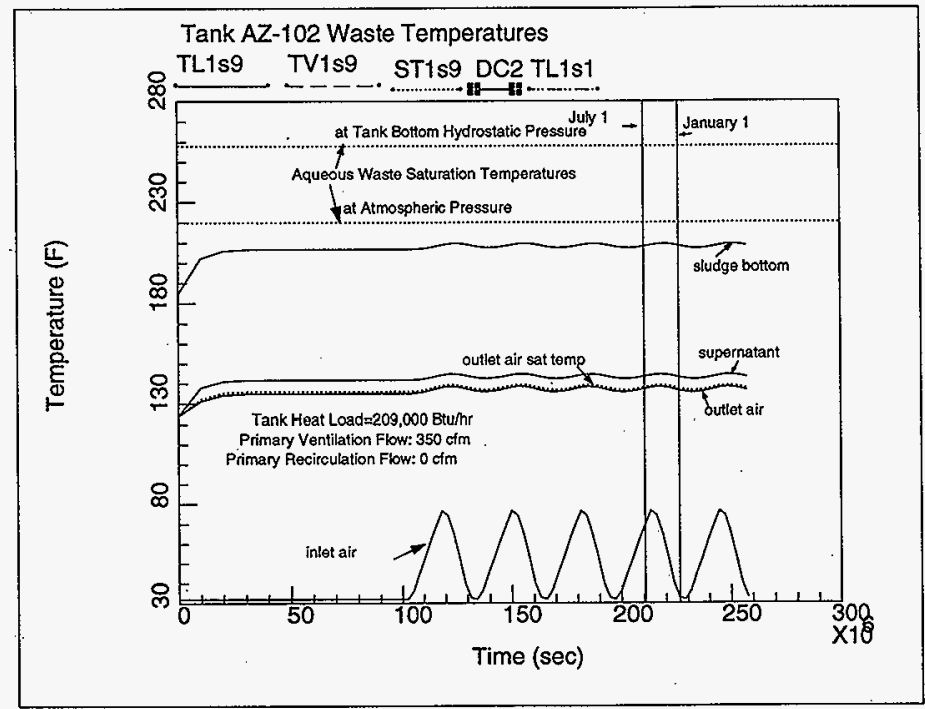


Figure 5.17 Tank 241-AZ-102 Waste Sludge and Supernatant Temperatures and Ventilation Flow Inlet and Outlet Temperatures For 702-A Current Operating System

With $580 \mathrm{scfm}$ Ambient Inleakage Flow and Heat Load of 209,000 Btu/hr.

az102r3ng

Sun Sep' 7 15:34:06 1997

GOTH Version 3.4 - April 1991

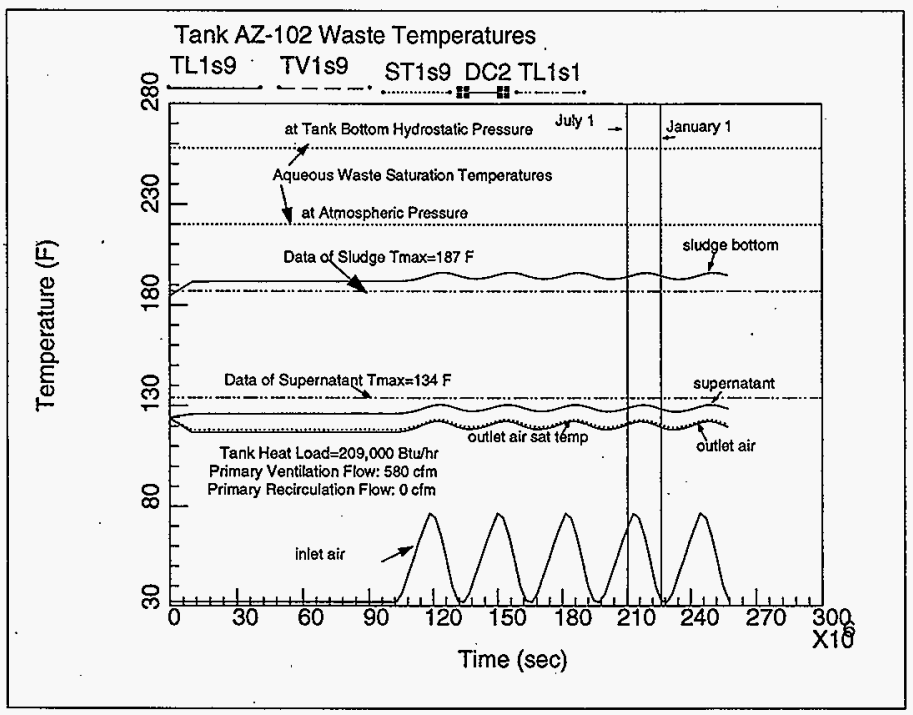


Table 5.2 Tank 241-AZ-102 Waste Temperatures For Different Primary Ventilation Flows

\begin{tabular}{|l|l|l|l|l|}
\hline \begin{tabular}{l} 
Primary $\begin{array}{l}\text { Ventilation } \\
\text { Ambient Flow, } \\
\text { scfm }\end{array}$ \\
\hline 100
\end{tabular} & $\begin{array}{l}\text { Primary } \\
\text { Ventilation } \\
\text { Recirculation } \\
\text { Flow, scfm }\end{array}$ & $\begin{array}{l}\text { Sludge Peak } \\
\text { Temperature, } \\
{ }^{\circ} \mathrm{F}\end{array}$ & $\begin{array}{l}\text { Supernatant } \\
\text { Peak } \\
\text { Temperature, } \\
{ }^{\circ} \mathrm{F}\end{array}$ & $\begin{array}{l}\text { Tank Heat } \\
\text { Load, Btu/hr }\end{array}$ \\
\hline 100 & 400 & 198 & 137 & 193,600 \\
\hline 200 & 0 & 237 & 177 & 193,600 \\
\hline 350 & 0 & 218 & 159 & 193,600 \\
\hline 350 & 0 & 203 & 143 & 193,600 \\
\hline 350 & 0 & 205 & 143 & 199,500 \\
\hline 400 & 0 & 209 & 144 & 209,000 \\
\hline 580 & 0 & 200 & 139 & 193,600 \\
\hline
\end{tabular}

\subsection{Tank 241-AY-101}

GOTH model for the tank 241-AY-101 with $~ 3 \mathrm{ft}$ of sludge having heat sources of 3.263 $\mathrm{Btu} / \mathrm{hr}-\mathrm{ft} 3$ and $\sim 25 \mathrm{ft}$ supernatant with no heat sources was used along with ambient meteorological conditions. The sludge thermal conductivity is assumed to be $0.42 \mathrm{Btu} / \mathrm{hr}-\mathrm{ft}-$ ${ }^{\circ} \mathrm{R}$. Based on the tank waste characterization data (Thompson, 1996), the heat generation estimated from radioactive decay was $33,700 \mathrm{Btu} / \mathrm{hr}$ from 1996 analytical results while the HTCE (Brevick, 1995) estimation was $49,400 \mathrm{Btu} / \mathrm{hr}$. The most recent tank temperature data from the SACS database (WHC, 1996) for the year 1996-1997 shows that the sludge temperatures range from 85 to $116^{\circ} \mathrm{F}$ and the supernatant temperatures range from 68 to $76^{\circ} \mathrm{F}$. . The tank heat load has been established to be about $41,000 \mathrm{Btu} / \mathrm{hr}$ from thermal hydraulic analysis (Sathyanarayana, 1997) using the measured liquid evaporation rates and waste temperatures. The current 702-A primary ventilation system has been assumed to provide $550 \mathrm{scfm}$ ambient inleakage flow to the tank and using GOTH model of tank AY-101 thermal hydraulic calculations were performed to establish current operating waste temperatures. Figure 5.18 shows the results of waste temperatures indicating peak temperatures of sludge and supernatant at $116^{\circ} \mathrm{F}$ and $80^{\circ} \mathrm{F}$ respectively. The liquid evaporation rate is shown in Figure 5.19 and the heat balance results are presented in Figure 5.20. It can be seen from 
Figure 5.18 Tank 241-AY-101 Waste Sludge and Supernatant Temperatures and Ventilation Flow Inlet and Outlet Temperatures For 702-A Current Operating System With $550 \mathrm{scfm}$ Ambient Inleakage Flow and Heat Load of 41,000 Btu/hr.

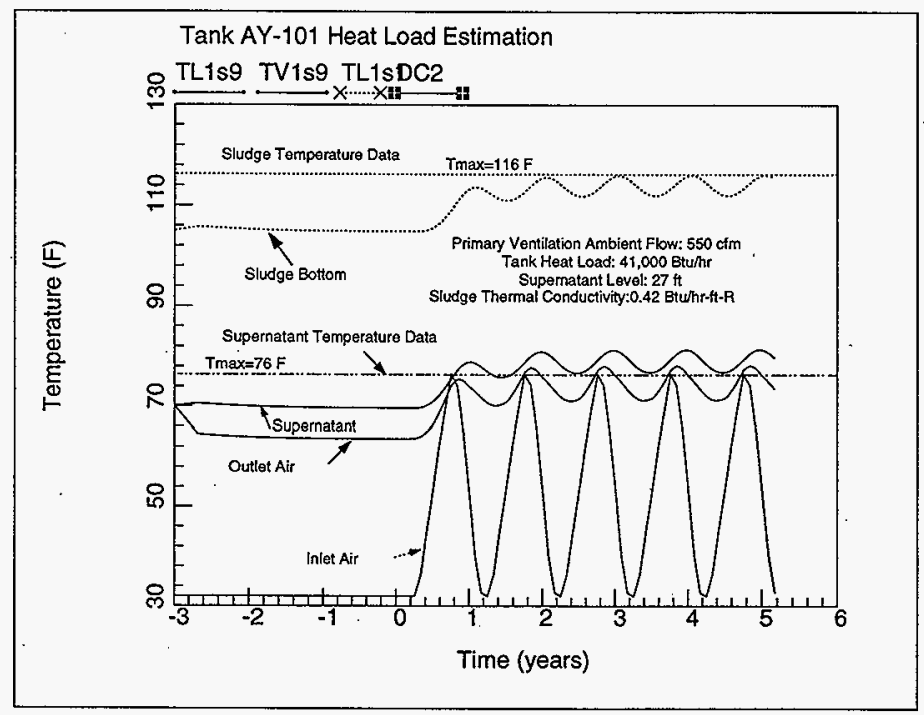


HNF-SD-W030-ER-004 Rev. 0

Figure 5.19 Tank 241-AY-101 Liquid Waste Evaporation For 702-A Current Operating System With $550 \mathrm{scfm}$ Ambient Inleakage Flow and Heat Load of 41,000 Btu/hr.

ay101r42

Mon Sep 1 14:40:45 1997

GOTH Version 3.4 - April 1991

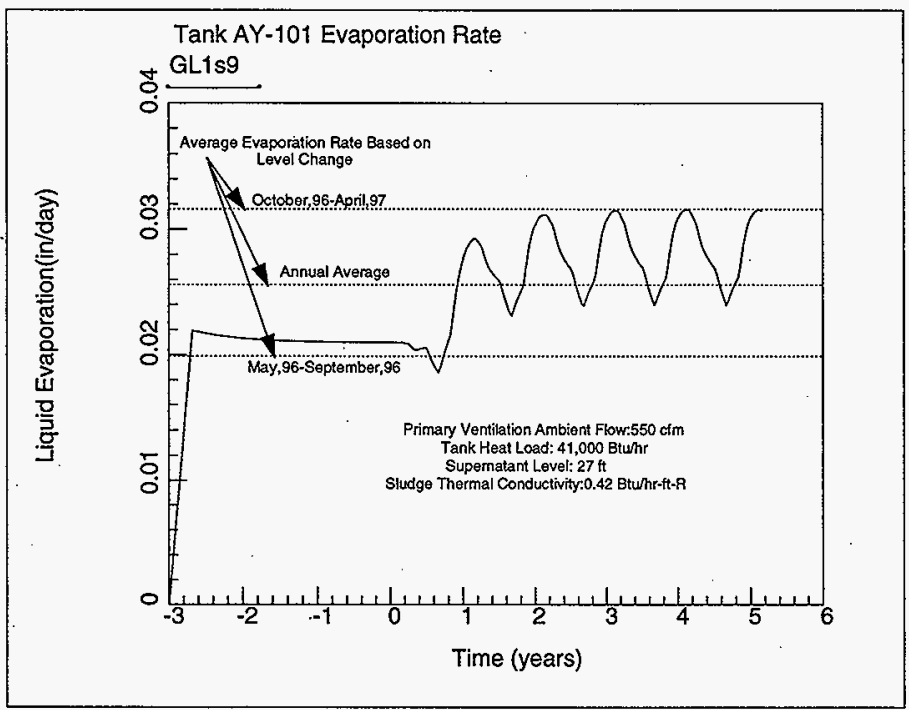


Figure 5.20 Tank 241-AY-101 Evaporation and Sensible Heat Loss For 702-A Current Operating System With $550 \mathrm{scfm}$ Ambient Inleakage Flow and Heat Load of $41,000 \mathrm{Btu} / \mathrm{hr}$.

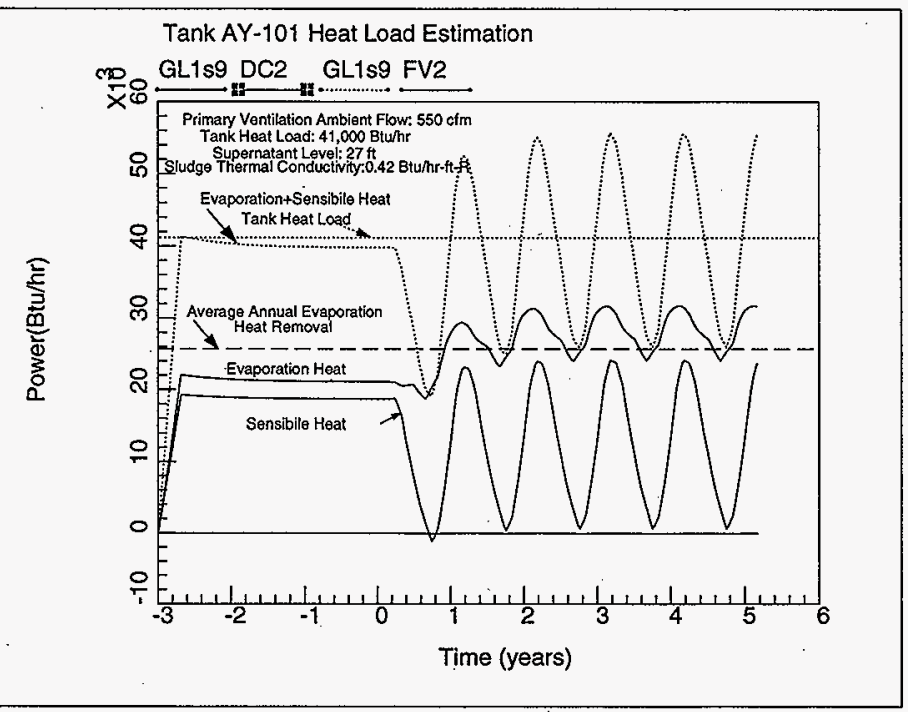


these results that the tank should have a heat load of $41,000 \mathrm{Btu} / \mathrm{hr}$ to maintain a peak liquid evaporation rate of $0.0316 \mathrm{in} /$ day ( $~ 87$ gallons/day). The tank $241-\mathrm{AY}-101$ with a heat load of $41,000 \mathrm{Btu} / \mathrm{hr}$ for the current tank contents if operated using the new W-030 ventilation system in recircula tion mode, the waste temperatures are estimated to be higher by about $21^{\circ} \mathrm{F}$. Figure 5.21 shows the predicted waste temperatures with the new (W-030) ventilation system. The higher operating temperatures should be expected as the W-030 system is not as effective as the current ventilation system in providing cooling to the tanks. However, the peak temperatures of the waste are well below safety limits for this tank. The thermal hydraulic calculations were also performed for this tank under bypass mode of operation of W-030 system. For this mode of operation, two ambient inleakage flows of 100 and 150 scfm were considered. The waste temperatures for these two cases are shown in Figures 5.22 and 5.23. The peak sludge and supernatant temperatures are summarized in Table 5.3. For the tank 241-AY-101, even $100 \mathrm{scfm}$ ambient inleakage flow should be sufficient to maintain the waste temperatures within safety operating limits.

Table 5.3 Tank 241-AY-101 Waste Temperatures for Different Ventilation Flows

\begin{tabular}{|l|l|l|l|}
\hline $\begin{array}{l}\text { Ambient Vent } \\
\text { Inleakage Flow, } \\
\text { scfm }\end{array}$ & $\begin{array}{l}\text { Sludge Peak } \\
\text { Temperature, }{ }^{\circ} \mathrm{F}\end{array}$ & $\begin{array}{l}\text { Supernatant } \\
\text { Temperature, }{ }^{\circ} \mathrm{F}\end{array}$ & Heat Load, Btu/hr \\
\hline $\begin{array}{l}\text { 702-A System with } \\
550 \text { scfm }\end{array}$ & 116 & 80 & 41,000 \\
\hline $\begin{array}{l}\text { 702-AZ System(W- } \\
\text { 030) with 100 scfm } \\
\text { ambient inleakage } \\
\text { and 400 scfm } \\
\text { recirculation Flow }\end{array}$ & 135 & 101 & 41000 \\
\hline 100 & 156 & 123 & 41000 \\
\hline 150 & 145 & 111 & 41000 \\
\hline
\end{tabular}


Figure 5.21 Tank 241-AY-101 Waste Sludge and Supernatant Temperatures and Ventilation Flow Inlet and Outlet Temperatures For 702-A Current Operating System With $100 \mathrm{scfm}$ Ambient Inleakage Flow and Heat Load of 41,000 Btu/hr.

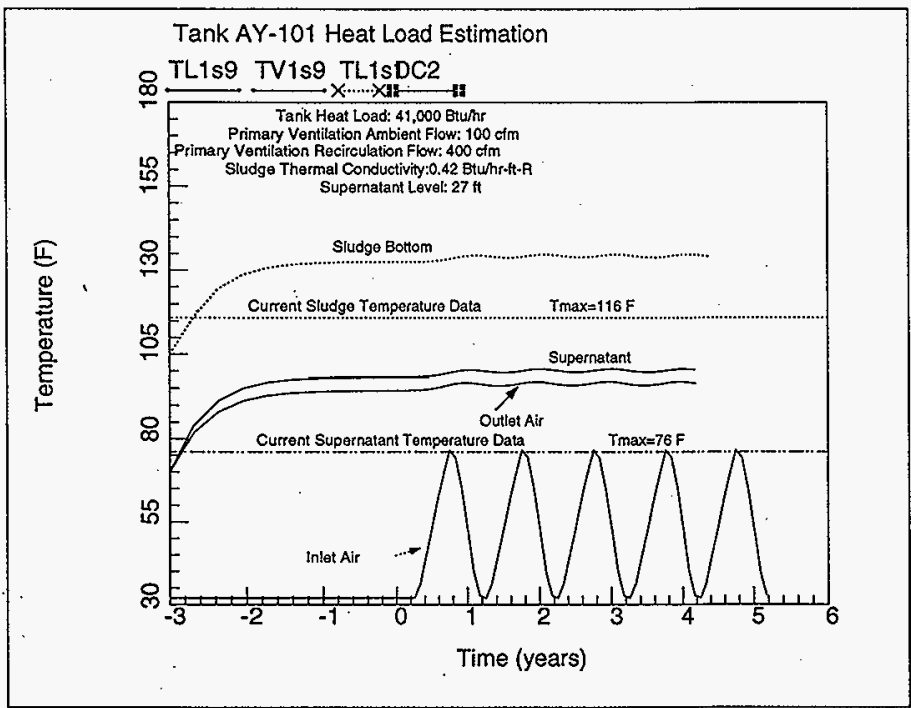


Figure 5.22 Tank 241-AY-101 Waste Sludge and Supernatant Temperatures and Ventilation Flow Inlet and Outlet Temperatures For W-030 System Operating in Bypass Mode With $100 \mathrm{scfm}$ Ambient Inleakage Flow and Heat Load of 41,000 Btu/hr

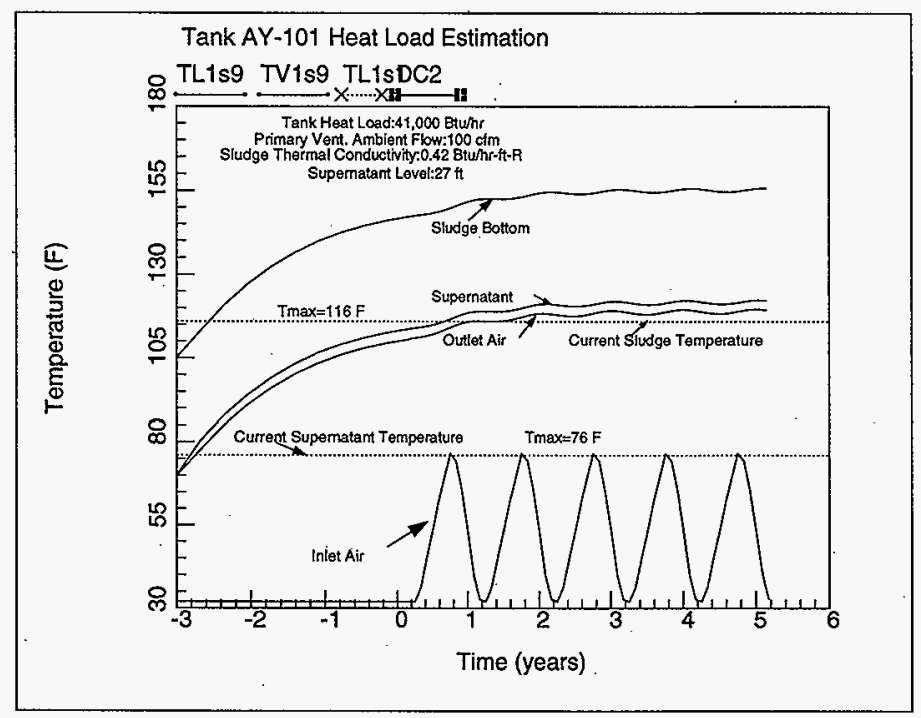


Figure 5.23 Tank 241-AY-101 Waste Sludge and Supernatant Temperatures and Ventilation Flow Inlet and Outlet Temperatures For W-030 System Operating in Bypass Mode With 150 scfm Ambient Inleakage Flow and Heat Load of 41,000 Btu/hr

cay101:42

Thu Sep 11 10:12:05 1997

GOTH Version 3.4 - April 1991

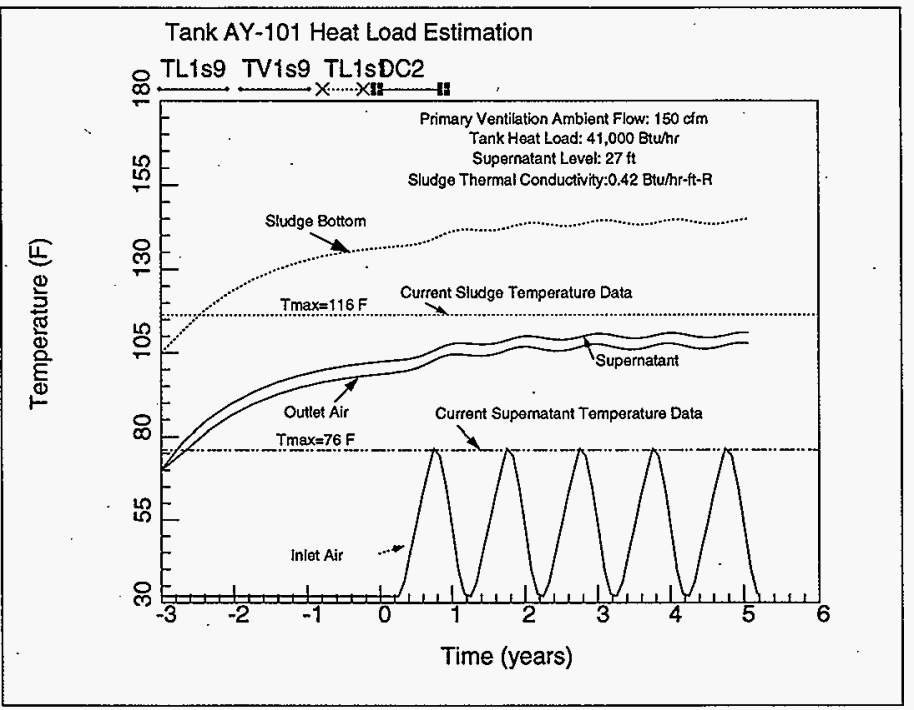




\subsection{Tank 241-AY-102}

GOTH model for the tank 241-AY-102 with $1 \mathrm{ft}$ of sludge with a heat source of 8.229 $\mathrm{Btu} / \mathrm{hr}-\mathrm{ft} 3$ and $24 \mathrm{ft}$ of supernatant with no heat source was used for the thermal hydraulic analysis to establish the minimum required ambient inleakage flow for safe operation of the tank under W- 030 bypass mode of operation. The sludge thermal conductivity was assumed to be $0.35 \mathrm{Btu} / \mathrm{hr}-\mathrm{ft}-{ }^{-} \mathrm{R}$. Annulus ventilation system was assumed to be not operating. The ambient air inlet flow conditions were that of 1995 monthly averaged Hanford meteorological conditions. The annual cycle conditions were preceded by an assumed winter average conditions. The recirculation loop tank inlet flow is assumed at $83{ }^{\circ} \mathrm{F}$ and $100 \%$ relative humidity. First the waste temperatures were established for the tank heat load of $33,000 \mathrm{Btu} / \mathrm{hr}$ using an assumed air inleakage flow of $550 \mathrm{scfm}$ from the current ventilation system. The waste temperature for this ventilation flow are shown in Figure 5.24. The peak sludge temperature of $86^{\circ} \mathrm{F}$ and supernatant temperature of $76^{\circ} \mathrm{F}$ was estimated and these are close to the measured values. Also shown in Figure 5.25 the liquid evaporation rate which is slightly higher than the measured value of 0.02 in/day. The heat balance of the Tank 241-AY-102 for the case with $550 \mathrm{scfm}$ from the current 702-A ventilation system is shown in Figure 5.26 indicating the amount of heat loss due to evaporation and sensible heat. The waste temperatures in Tank AY-102 under the operation of W-030 system in recirculation mode were also predicted and are shown in Figure 5.27. The peak sludge temperatures will increase to $106^{\circ} \mathrm{F}$ and supernatant temperature will increase to 97 . $^{\circ} \mathrm{F}$. Even in this case, the changeover to W-030 system will result in higher waste temperatures of about $20^{\circ} \mathrm{F}$. For bypass mode of operation of W-030 system, the waste temperatures were estimated using only ambient inleakage flow of 100 and $150 \mathrm{scfm}$. The waste temperatures for these two ventilation flow cases are shown in Figures 5.28 and 5.29 respectively. The waste peak temperatures even with $100 \mathrm{scfm}$ flow are well below safe operating values. The sludge peak temperatures and supernatant temperatures for all the cases considered are summarized in Table 5.4.

Table 5.4 Tank AY-102 Waste Temperatures for Different Ventilation Flows

\begin{tabular}{|l|l|l|l|l|}
\hline $\begin{array}{l}\text { Ambient } \\
\text { Inleakage Flow, } \\
\text { scfm }\end{array}$ & $\begin{array}{l}\text { Recirculation } \\
\text { Flow, scfm } \\
\ldots\end{array}$ & $\begin{array}{l}\text { Sludge Peak } \\
\text { Temperature, } \\
{ }^{\circ} \mathrm{F}\end{array}$ & $\begin{array}{l}\text { Supernatant } \\
\text { Temperature, } \\
{ }^{\mathrm{F}}\end{array}$ & $\begin{array}{l}\text { Heat Load, } \\
\mathrm{Btu} / \mathrm{hr}\end{array}$ \\
\hline $\begin{array}{l}550 \text { (702-A } \\
\text { Vent System) }\end{array}$ & 0 & 86 & 76 & 33,000 \\
\hline 100 & $\begin{array}{l}400(702-\mathrm{AZ} \\
\text { System) }\end{array}$ & 106 & 97 & 33,000 \\
\hline 100 & 0 & 122 & 113 & 33,000 \\
\hline 150 & 0 & 111 & 102 & 33,000 \\
\hline
\end{tabular}


Figure 5.24 Tank 241-AY-102 Waste Sludge and Supernatant Temperatures and Ventilation Flow Inlet and Outlet Temperatures For 702-A Current Operating System With $550 \mathrm{scfm}$ Ambient Inleakage Flow and Heat Load of 33,000 Btu/hr.

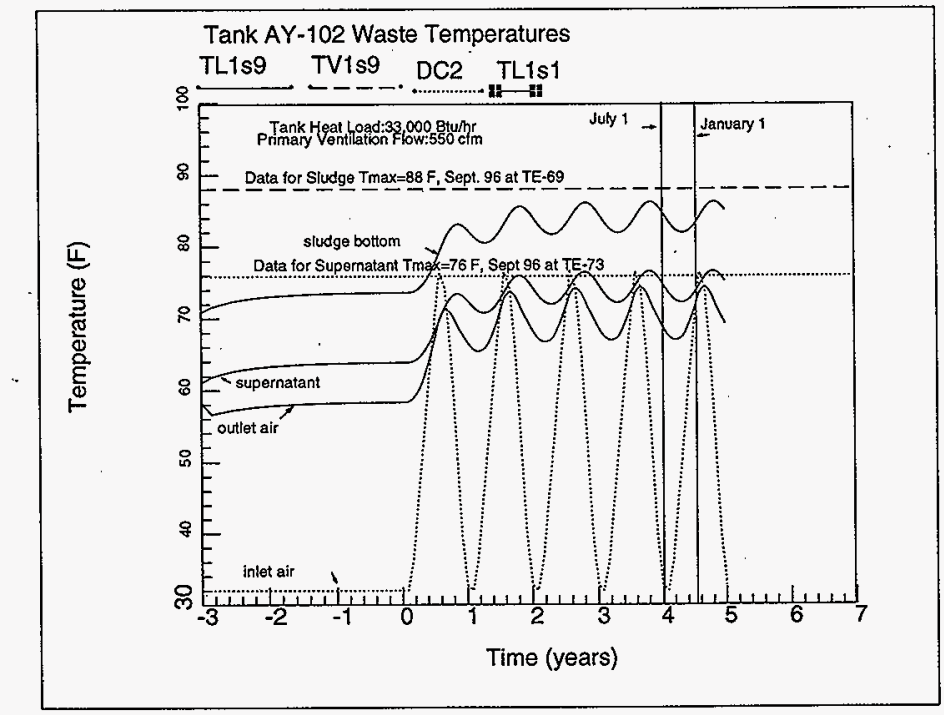


HNF-SD-W030-ER-004 Rev. 0

Figure 5.25 Tank 241-AY-102 Liquid Waste Evaporation For 702-A Current Operating System With $550 \mathrm{scfm}$ Ambient Inleakage Flow and Heat Load of 33,000 Btu/hr.

ay 10264

Wed Sep 3 10:14:03 1997

GOTH Version 3.4 - April 1991

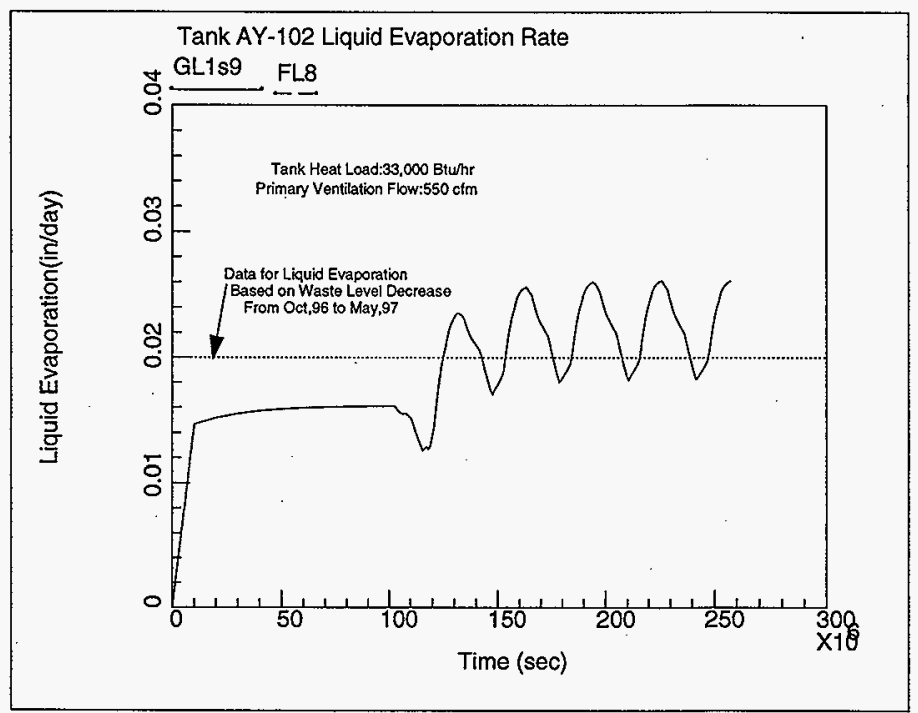


Figure 5.26 Tank 241-AY-101 Evaporation and Sensible Heat Loss For 702-A Current Operating System. With $550 \mathrm{scfm}$ Ambient Inleakage Flow and Heat Load of 33,000 Btu/hr.

ay $102 \mathrm{r} 4$

Thu Jul 31 11:56:20 1997

GOTH Version 3.4 - April 1991

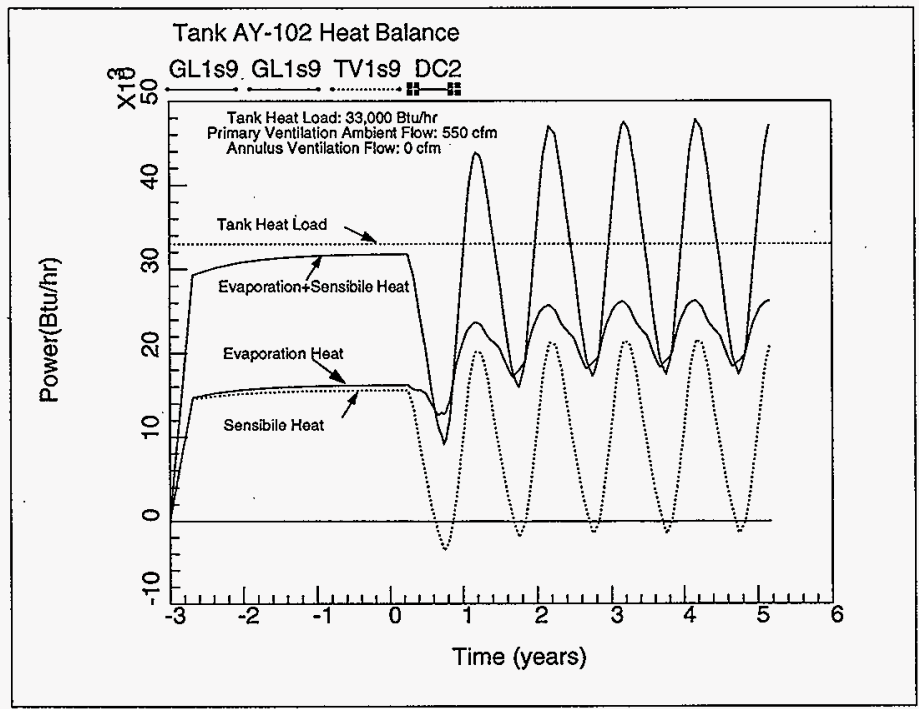


Figure 5.27 Tank 241-AY-102 Waste Sludge and Supernatant Temperatures and Ventilation Flow Inlet and Outlet Temperatures For 702-AZ (W-030) System Operating in Recirculation Mode With Heat Load of 33,000 Btu/hr.

ay $102 \pi 4 n$

Wed Sep 3 10:25:11 1997

GOTH Version 3.4 - April 1991

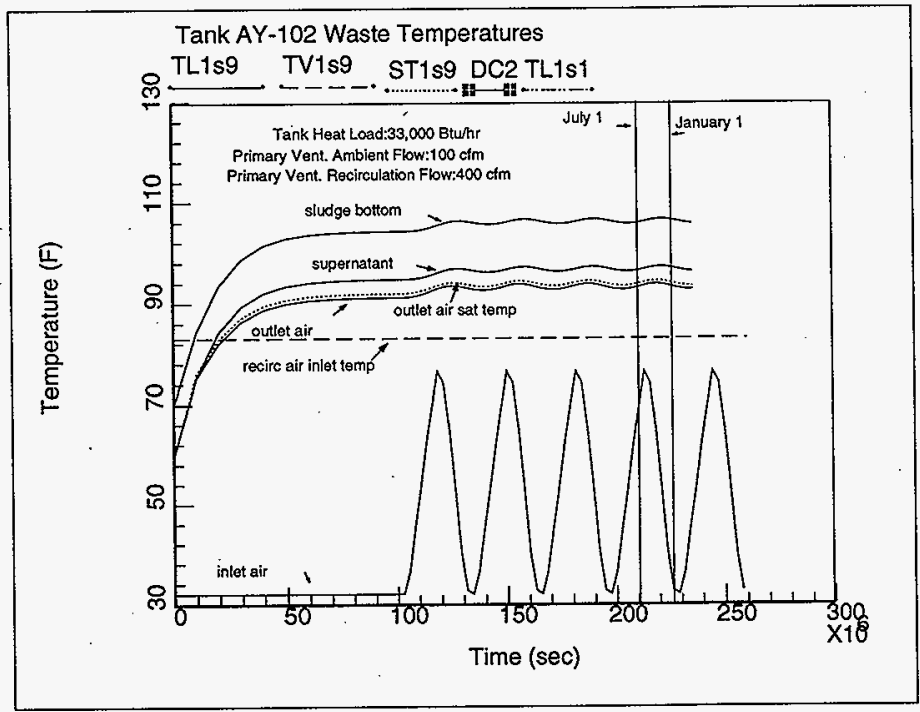


Figure 5.28 Tank 241-AY-102 Waste Sludge and Supernatant Temperatures and Ventilation Flow Inlet and Outlet Temperatures For 702-A Current Operating System With $100 \mathrm{scfm}$ Ambient Inleakage Flow and Heat Load of 33,000 Btu/hr.

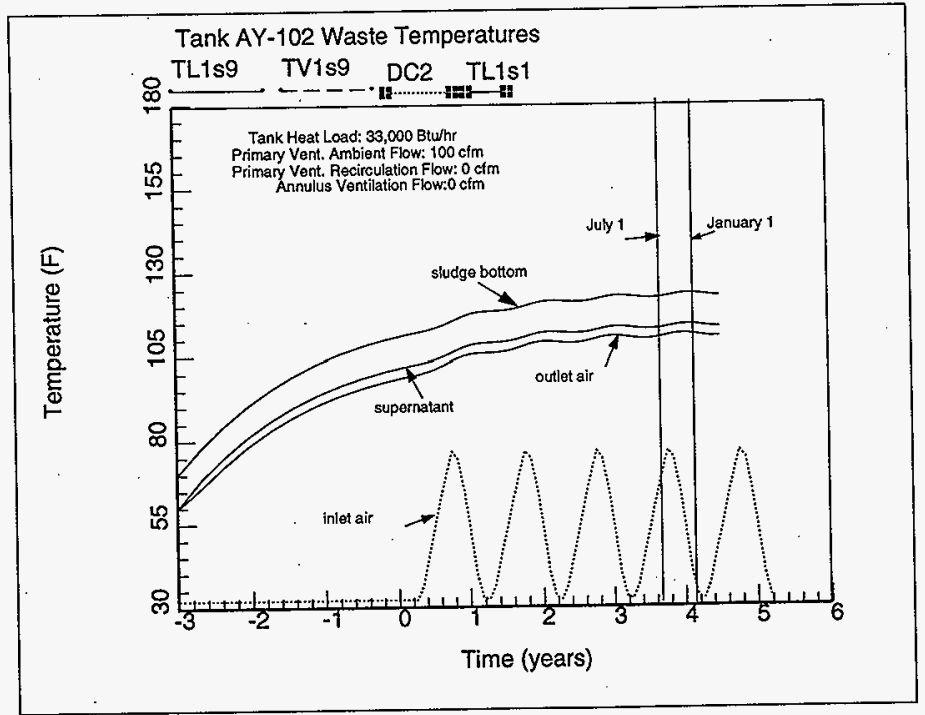


Figure 5.29 Tank 241-AY-102 Waste Sludge and Supernatant Temperatures and Ventilation Flow Inlet and Outlet Temperatures For 702-A Current Operating System With $150 \mathrm{scfm}$ Ambient Inleakage Flow and Heat Load of 33,000 Btu/hr.

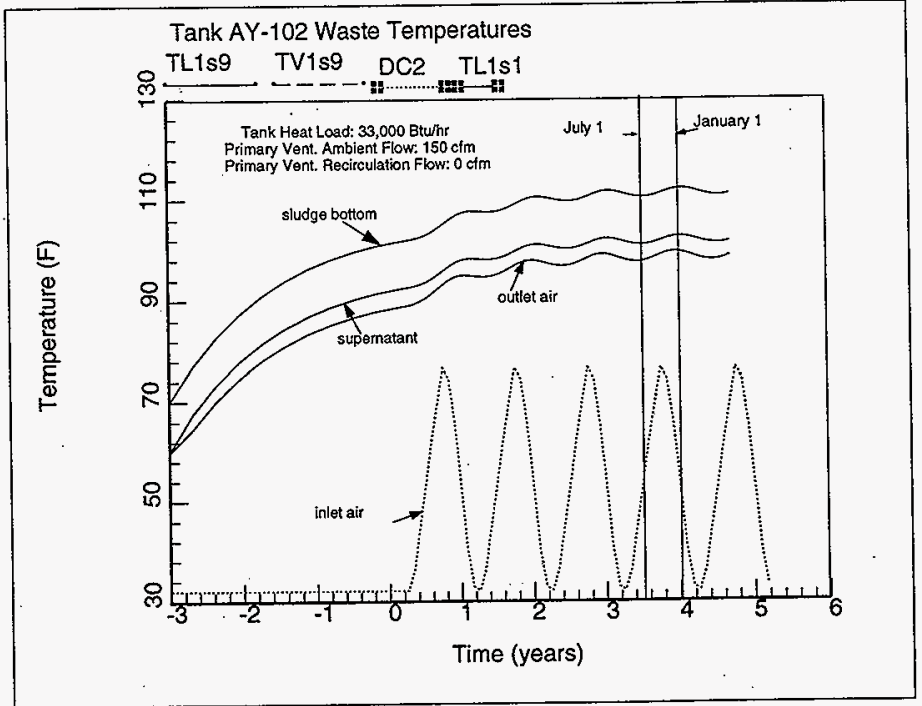




\subsection{Conclusions and Recommendations}

Under bypass mode of operation of W-030 primary ventilation system, the AY/AZ tank farm aging waste tanks with current heat load conditions can be safely operated by distributing the available $1000 \mathrm{scfm}$ air flow among all four tanks as shown in Table 6.1. The heat load values assumed in this analysis were based on the radiactive decay estimation for tanks in $A Z$ Farm and on heat balance estimation with thermal analysis for tanks in AY Farm. The peak saturation temperatures for waste in these tanks based on current contents varies from 250 to $258^{\circ} \mathrm{F}$ at the tank bottom. The maximum operating peak sludge temperatures should be $30^{\circ} \mathrm{F}$ below local saturation temperature. The ambient air inleakage flow for tanks in $\mathrm{AZ}$ Tank farm should be kept around 350 scfm and for tanks in AY farm should be about 150 scfm in order to operate the tanks safely both from waste temperatures point of view and flammable gas risk considerations. Table 6.1 summarizes the results of thermal hydraulic analysis at the recommended operating conditions.

\begin{tabular}{|l|l|l|l|l|}
\hline Tank & AZ-101 & AZ-102 & AY-101 & AY-102 \\
\hline $\begin{array}{l}\text { Current Heat } \\
\text { Load, Btu/hr }\end{array}$ & 241,600 & $\begin{array}{l}193,600 \text { to } \\
209,000\end{array}$ & 41,000 & 33,000 \\
\hline $\begin{array}{l}\text { W-030 Design } \\
\text { Heat Removal } \\
\text { in Recirculation } \\
\text { Mode, Btu/hr }\end{array}$ & $1,661,000$ & $1,000,000$ & $1,000,000$ & $1,000,000$ \\
\hline $\begin{array}{l}\text { Ambient } \\
\text { Ventilation } \\
\text { Flow Rate in } \\
\text { By-pass Mode, } \\
\text { scfm }\end{array}$ & 350 & 350 & 150 & 150 \\
\hline $\begin{array}{l}\text { Supernate } \\
\text { Temperature in } \\
\text { By-pass Mode, } \\
{ }^{\circ} \mathrm{F}\end{array}$ & 150 & 143 to 144 & 111 & 102 \\
\hline $\begin{array}{l}\text { Peak Sludge } \\
\text { Temperature in } \\
\text { By-Pass Mode, } \\
{ }^{\circ} \mathrm{F}\end{array}$ & 200 & 203 to 209 & 145 & 111 \\
\hline
\end{tabular}

Therefore, the recommended operating conditions will maintain the peak sludge temperatures in all the four tanks below the safe operating limit of $30^{\circ} \mathrm{F}$ below local saturation temperature. 
HNF-SD-W030-ER-004 Rev. 0

\subsection{References}

Brevick, C.H., L.A. Gaddis, and S.D. Consort, 1995, Supporting Document for the Historical Tank Content Estimate for AY Tank Farms, WHC-SD-WM-ER-317, Rev.0, Westinghouse Hanford Company, Richland, Washington.

Hodgson, K. M., 1995, Tank Characterization Report for Double-Shell Tank 241-AZ101, WHC-SD-WM-ER-410 Rev.0, Westinghouse Hanford Company, Richland, Washington.

Hoitink, D. J. And K. W. Burk, 1996, Climatological Data Summary 1995 with Historical Data, PNNL-11107, UC-603, Pacific Northwest National Laboratory, Richland, Washington.

MacLean, G.T., 1995, Personal Communication.

Sathyanarayana, K., 1994, Summary Report: Thermal Hydraulic Safety Analysis of Aging Waste Tank 101-AZ, WHC-SD-WM-ER-335, Rev.0, Westinghouse Hanford Company, Richland, Washington.

Sathyanarayana, K., 1996, Thermal Hydraulic Evaluation of Consolidating Tank C-106 Waste into Tank $A Y-102$, WHC-SD-WM-ER-534, Rev.0, Westinghouse Hanford Company, Richland, Washington.

Sathyanarayana, K., 1997, Thermal Hydraulic Analysis of Tank 241-AY-101, NHC-9757900, Numatec Hanford Company, Richland, Washington.

Sathyanarayana, K., 1997, Project W-320 Thermal Evaluation, HNF-SD-WM-ER-002, Rev.0, Numatec Hanford Company, Richland, Washington.

Schreiber, R. D.,1995, Tank Characterization Report for Double-Shell Tank 241-AZ-102, WHC-SD-WM-ER-411 Rev.0A, Westinghouse Hanford Company, Richland, Washington.

Thompson, R. R. and R.H. Stephens, 1995, Tank Characterization Report for Double-Shell Tank 24l-AY-101, WHC-SD-WM-ER-405 Rev.0, Westinghouse Hanford Company, Richland, Washington.

WHC, 1994, Hanford Site Tank Farm Facilities Interim Safety Basis, WHC-SD-WM-ISB-001, Westinghouse Hanford Company, Richland, Washington.

WHC-1996, Surveillance Analysis Computer System Database, June 14, 1996. 


\section{DISTRIBUTION SHEET}

\begin{tabular}{|c|c|c|c|c|c|}
\hline \multirow{2}{*}{$\begin{array}{l}\text { To } \\
\text { Distribution }\end{array}$} & \multirow{2}{*}{\multicolumn{3}{|c|}{$\begin{array}{l}\text { From } \\
\text { Process Engineering Analysis }\end{array}$}} & \multicolumn{2}{|l|}{ Page 1 of 1} \\
\hline & & & & \multicolumn{2}{|c|}{ Date $9 / 10 / 97$} \\
\hline \multirow{2}{*}{\multicolumn{4}{|c|}{$\begin{array}{l}\text { Project Title/Work Order } \\
\text { W-030/NB604 }\end{array}$}} & \multicolumn{2}{|c|}{ EDT No. 621712} \\
\hline & & & & \multicolumn{2}{|c|}{ ECN No. N/A } \\
\hline Name & MSIN & $\begin{array}{l}\text { Text } \\
\text { With All } \\
\text { Attach. }\end{array}$ & Text Only & $\begin{array}{l}\text { Attach./ } \\
\text { Appendix } \\
\text { Only }\end{array}$ & $\begin{array}{c}\text { EDT/ECN } \\
\text { Only }\end{array}$ \\
\hline
\end{tabular}

\section{NUMATEC}

S. R. Briggs

Tarik Choho

A.M. Choho

K. A. Colosi

B. A. Crea

T. A. Flament

K. D. Fowler

B. C. Fryer

R. P. Marshall

W. C. Miller

D. M. Ogden

K. Sathyanarayana (5)

J. P. Sloughter

Central Files (Original +7 )

$\begin{array}{ll}\text { R3-25 } & x \\ \text { R3-47 } & x \\ H 6-35 & x \\ \text { R3-25 } & x \\ \text { R3-25 } & x \\ \text { K9-46 } & x \\ \text { R2-11 } & x \\ H 0-34 & x \\ H 5-61 & x \\ H 5-25 & x \\ H 0-34 & x \\ H 0-34 & x \\ H 0-34 & x \\ \text { A3-88 } & x\end{array}$

Lochheed Martin Hanford Corporation

G. P. Hopkins

M. N. Islam

J. R. Kriskovich

S. R. Pierce

W. J. Powell

J. W. Lentsch

L. B. McDaniel

W. T. Thompson

Duke Engineering Services Hanford

K. H. Morris

C. E. Leach

\section{SGN Eurisys Services Corp.}

G. T. MacLean

H5-6I $\quad x$

$\begin{array}{ll}\text { S5-03 } & x \\ \text { S5-12 } & \dot{x} \\ \text { RI-56 } & x \\ \text { S5-05 } & x \\ \text { S5-13 } & x \\ \text { S2-48 } & x \\ H 7-06 & x \\ H 5-24 & x\end{array}$

$R 1-49$
$R 1-49$ 